\title{
A Comprehensive Review on Adenoviruses Infections in Fowl: Epidemiology, Forms, Diagnosis, and Control
}

\author{
Wafaa A. Abd El-Ghany \\ Poultry Diseases Department, Faculty of Veterinary Medicine, Cairo University, 1211, Giza, Egypt \\ *Corresponding author's E-mail:wafaa.ghany@yahoo.com; ORCID: 0000-0003-1686-3831
}

Received: 10 Apr. 2021

Accepted: 18 May 2021

\begin{abstract}
Fowl Adeno Viruses (FAdVs) are non-enveloped and double-stranded DNA viruses. They include eight species (FAdVs A-E) and 12 serotypes (FAdVs-1 to $-8 \mathrm{a}$ and $-8 \mathrm{~b}$ to -11 ). Strains of FAdVs have been widely distributed in different countries all over the world. Most avian species are susceptible to FAdVs infections. Vertical, horizontal, and mechanical infections and transmissions have been recorded in different forms of FAdVs infection. There are many forms of FAdVs infections according to the groups (including three groups) of the virus. Group 1 usually causes inclusion body hepatitis, hydropericardium syndrome, quail bronchitis, pancreatic erosions, gizzard erosion, cardiovascular, hematopoietic, and respiratory systems disorders. Group II is incriminated in diseases, such as turkey hemorrhagic enteritis, marble spleen disease in pheasants, and splenomegaly in chickens. In addition, group III is responsible for egg drop syndrome in laying chickens. Diagnosis of FAdVs infections is not based on the signs and lesions. However, microscopic detection of specific lesions and inclusion bodies may be suggestive. Diagnosis is mainly based on the conventional traditional isolation in embryonated eggs of different avian species as well as on tissue culture of avian origin. Molecular diagnostic techniques are now widely used for rapid and confirmative detection of FAdVs. The application of sanitary and hygienic measures in poultry farms is very important to prevent FAdVs outbreaks. However, different types of inactivated, living attenuated as well as recombinant vaccines have been developed and used in several countries to overcome different forms of FAdVs. Therefore, this review article deals with the FAdVs susceptibility and transmission, the etiological agent, forms of infections, and diagnosis as well as different methods of prevention and control.
\end{abstract}

Keywords: Egg drop syndrome, Fowl adenoviruses, Hydropericardium syndrome, Inclusion body hepatitis, Quail bronchitis, Turkey hemorrhagic enteritis.

\section{INTRODUCTION}

During the last decade, the incidence of viral diseases of poultry has been increased. Adenoviruses isolated from poultry are termed as Fowl Adenovirus(s) (FAdVs). These viruses are a diverse group of pathogens that cause a variety of important infections in poultry (Fadly and Winterfield, 1973). Reduced humoral and cell-mediated immune competence to various antigens and vaccines is the immunosuppressive potential of FAdVs (Singh et al., 2006; Schonewille et al., 2008).

Avian adenoviruses are non-enveloped and doublestranded DNA viruses (Hess, 2000; Zhao et al., 2015). There are eight species (FAdVs A to E) (Hess, 2000) and 12 (FAdVs-1 to $-8 \mathrm{a}$ and $-8 \mathrm{~b}$ to -11 ) serotypes of FAdVs
(Meulemans et al., 2004). Several outbreaks of FAdVs infections have been demonstrated in poultry farms worldwide as in the USA, Europe, Australia, and Asia. For example, strains of FAdVs-2, $-11,-7$, and -8 have been detected in Europe and FAdVs -7 in North America (Grgic et al., 2011; Kajan et al., 2013; Schachner et al., 2016), FAdVs-4 in Asia (Park et al., 2017; Niu et al., 2018) and FAdV-2 and FAdV-8b in South Africa (Joubert et al., 2014; Maartens et al., 2014).

The pathogenesis of FAdVs infection is affected by the serotypes or genotypes of the virus. The pathogenicity of FAdVs varies from 10-90\% depending on the virulence of the virus strain (Li et al., 2017; Schachner et al., 2018). The disease conditions associated with FAdVs infections can vary based on the group of the virus. Group 1 may 
cause Inclusion Body Hepatitis (IBH, Zhao et al., 2015), Hydropericardium Syndrome (HPS, Schonewille et al., 2008; Zhao et al., 2015), Quail Bronchitis (QB, Olsen, 1950), pancreatic erosions (McFerran and Smyth, 2000; Nakamura et al., 2002), Gizzard Erosion (GE, Blicharz et al., 2011; Mase and Nakamura, 2014) and cardiovascular, hematopoietic and respiratory systems disorders (Cheema et al., 1989; Erny et al., 1995). Group II is considered as the cause of diseases like Turkey Hemorrhagic Enteritis (THE), Marble Spleen Disease (MSD) in pheasants, and splenomegaly in chickens. In addition, group III is responsible for Egg Drop Syndrome (EDS) in laying chickens (McFerran et al., 1978; Del Valle et al., 2020). Different forms of FAdVs infections in poultry are summarized in Figure 1.

Accordingly, the present review article focused on FAdVs infections regarding susceptibility and transmission of infection, causative agent, different forms of infections, diagnosis along with prevention and control methods.

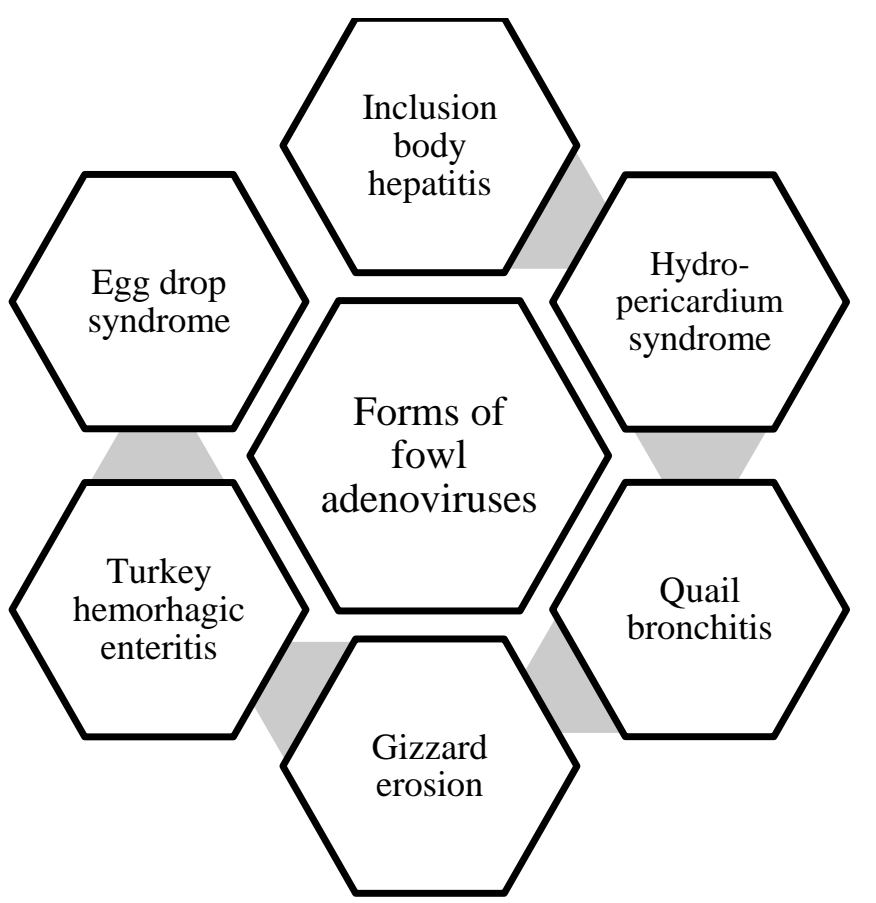

Figure 1. Different forms of fowl adenoviruses infections in poultry

\section{Susceptibility to fowl adenoviruses}

Fowl adeno viruses are heterogeneous and have been detected in at least 40 species of vertebrates, including mammals, birds, amphibians, reptiles, and fish (Benko and Harrach, 2003; Ko, 2005). Infections with FAdVs are known as ubiquitous primary or secondary pathogens and have been isolated from either healthy or diseased birds (Toro et al., 2000; Niczyporuk et al., 2012; Niczyporuk et al., 2013). Fowl adeno viruses have been commonly identified in different avian species such as chickens, turkeys, ducks, and gees (Hess, 2013; Pan et al., 2017a). About 31 wild bird species have been reported to have a role in the distribution of FAdVs outbreaks (Hess, 2000). It has been recorded that falcons (Singh et al., 2002; Mohamed et al., 2018), pigeons (Steer et al., 2009), wild black kites (Kumar et al., 2010), guinea fowl (Zellen et al., 1989), raptors (Ramis et al., 1992), parrots (Bradley et al.,
1994), kestrels (Schelling et al., 1989), tawny frogmouths (Rosen et al., 1965), and common buzzards (Frolich et al., 2002) are susceptible to FAdVs infections. It is clear that, as the age of the host increases, the degree of FAdVs multiplication in the host decreases, and consequently the losses also decrease (Rahimi and Minoosh, 2015).

\section{Transmission of fowl adenoviruses}

The transmission of FAdVs may occur vertically through eggs as the virus can spread from the dam to the offspring (Grgić et al., 2006; Philippe et al., 2007; Hafez, 2011, Hess, 2012). Viruses of adeno groups are rapidly transmitted among flocks (Cowen, 1992) through both oral-fecal (lateral) and mechanical means of infections. Airborne infection is a possible means of transmission, especially in QB infection (DuBose, 1967). Moreover, 
wild birds have a role in the spread of FAdVs infections as a mechanical means of FAdVs transmission.

Experimental inoculation of FAdVs liver homogenate using subcutaneous route succeded in the induction of typical disease conditions (Asrani et al., 1997; Chandra et al., 1997). However, the induction of FADVs was also reported by the route of oral inoculation (Naeem et al., 2001).

\section{The etiological agent}

Adenoviruses belong to the family Adenoviridae which is classified into five genera; Atadenovirus, Siadenovirus, Mastadenovirus, Aviadenovirus, and Ichtadenovirus (Davison et al., 2003). Avian adenoviruses belong to group 1 Aviadenovirus genus and family Adenoviridae. Group I includes 12 serotypes of FAdVs that are isolated from a variety of avian species with a common group of antigens (Kawamura et al., 1964; McFerran et al., 1975; Toro et al., 2000). Moreover, the viruses in group II share a common group of antigens that differentiates them from other groups (Domermuth et al., 1980).

By electron microscopy, FAdVs have been found to be non-enveloped, and contain linear 35-36 kbp doublestranded DNA with icosahedral morphology and a diameter of 70-90 nm (Nicklin et al., 2005; Steer et al., 2009; Robinson et al., 2011). The guanine/cytosine content of the viral DNA is $53-59 \%$. The genome of the virus encodes 40 proteins, and the ends of the viral genome are attached to terminal proteins. The genome of FAdVs consists of 13 structural proteins. The primary major structural viral proteins capsid include hexon, knobbed fiber, and penton (Russell, 2000; Russell, 2009) while the other minor structural proteins are cement proteins (VI, VIII, IX, IIIa) and core proteins (V, VII, Mu, terminal protein, IVa2, protease). The viral capsid consists of subunits of 720 hexon set as 240 trimers and 12 triangular penton capsomers with one or two protruded fibers (Viralzone, 2015). It has been demonstrated that penton and fiber interact with the receptors of infected cells during the viral penetration (Jucker et al., 1996; Fingerut et al., 2003).

The size of the hexon gene is different among the viruses according to the serotype, as the largest one contains 967 amino acids. There are four types of hexon; H1, H2, H3, and H4 (Burnett, 1985). The type H1 hexons are peripentonal, 60 in number, and associated with pentons at the 12 apices. The other hexons are a group of 9 on the 20 faces of the icosahedra. However, types $\mathrm{H} 2$ and $\mathrm{H} 3$ hexons are on the twofold and on the threefold axes, respectively, and the remaining ones are $\mathrm{H} 4$. There are nine hypervariable regions at the top of the hexon molecule (Saban et al., 2006). Hexons are highly susceptible to mutations due to the presence of these hypervariable regions. In addition, these hexons could be used for serotyping as they carry the major neutralizing epitope (Rux et al., 2003; Roberts et al., 2006; Matsushima et al., 2011).

The fiber contains receptors of cell surface binding and virulence epitopes. Thus, fiber protein is responsible for the attachment of the viral capsid to the host cell surface by its interaction with cellular receptors (Nicklin et al., 2005; Russell, 2009). It has been found that FAdVs have one long and other short fibers with different receptors. Thus, one fiber is responsible for virus attachment and the others are for internalization (Hess et al., 1995; Tan et al., 2001). The fiber consists of the knob, shaft, and tail. The fiber knob determines the haemagglutinating characters of the virus that are used for the classification of the viral species (A-F) (PehlerHarrington et al., 2004). Moreover, the knob plays an important role in the synthesis of fiber protein and encapsidation (Henning et al., 2006). It has been documented that the fiber comprises about 582 amino acids that bind to the penton base (Zubieta et al., 2005).

The penton consists of base and fiber protein. It has been documented that the penton base is sensitive to heat, trypsin, $\mathrm{pH}$, and changes in ionic strength (Wiethoff et al., 2005). The penton plays an important role in the penetration of the virus into the host cell (Fender et al., 2005), and interacts with cellular contents, as neutralizing antibodies against the penton have been detected in the sera (Hong et al., 2003). Furthermore, the penton interacts with capsomeres, hexons, and other proteins for stabilization of the capsid.

There are some types of important non-structural proteins named $100 \mathrm{~K}$ and $33 \mathrm{~K}$. The $100 \mathrm{~K}$ protein helps intracellular transport and folding of hexon during the replication of the viruses of groups B and C in insects (Hong et al., 2005). Antibodies against these proteins have been used to differentiate the vaccinated infected from non-vaccinated infected birds with FAdVs (Shah et al., 2015), as antibodies were detected in challenged chickens, but not vaccinated ones (Xie et al., 2013). It has been shown that FAdVs are resistant to dryness (Domermuth and Gross, 1971; Domermuth and Gross, 1972), as they can remain viable in contaminated carcasses or droppings for up to seven weeks. Accordingly, it is clear that FAdVs can survive among production cycles thorough out the cleaning and disinfection processes. 


\section{Forms of fowl adenovirus infections Inclusion body hepatitis}

Inclusion body hepatitis is an economically important acute disease affecting poultry worldwide (Schachner et al., 2016; Schachner et al., 2018). There are some other synonyms of IBH like Angara disease, Litchi heart disease, and infectious hydropericardium (AbdulAziz and Hassan, 1995; Mazaheri et al., 1998). The disease was first described in chicken flocks in the USA in 1963 (Helmboldt and Frazier, 1963), and then rapidly spread over the world, including Australia, Europe, Canada, India, Turkey, Saudi Arabia, and Egypt.

First, IBH is classified as group I FAdVs-8 (Reece et al., 1987; Erny et al., 1991). Later on, it has been found that all IBH virus strains isolated from chickens were assigned to FAdVs-1-8a,8b-12 serotypes, and species FAdVs-D and/or E (Morshed et al., 2017; Schachner et al., 2018). It has been shown that FAdV-4 is closely related to FAdV-10 using immunological and molecular techniques (Erny et al., 1991). A closer genetic relationship has been confirmed in FAdVs species D and E (Marek et al., 2013). Moreover, FAdVs-2, -3, -9 and -11 (D) as well as $-6,-7$ and $8 \mathrm{a}, \mathrm{b}(\mathrm{E})$ are considered as the causative agents of IBH (Ojkic et al., 2008; Steer et al., 2011; Schachner et al., 2016). Based on the genomic sequence of a nonpathogenic strain of FAdVs-11 and the pathogenic one, only $0.8 \%$ differences have been found among the nonpathogenic strains and the virulent ones (Absalón et al., 2017).

Epidemiological investigations on IBH outbreaks in Canada revealed that FAdVs-2, $-6,-7,-8$ a,b, and -11 (D) have been discovered in broiler flocks (Gomis et al., 2006; Ojkic et al., 2008; Grgic et al., 2011). In Japan, FAdVs-2 (D) strains were isolated from outbreaks in broiler farms in 2010 (Nakamura et al., 2011; Mase et al., 2012). Furthermore, FAdVs-8b (E) (Zadravec et al., 2013) and FAdVs-7 (Niczyporuk, 2017) in broiler chickens were confirmed to be the causative agent of IBH in Slovenia and Poland, respectively. Outbreaks caused by FAdVs-2, $4,-8 \mathrm{a}, \mathrm{b}$, and -11 have been reported in New Zealand (Christensen and Saifuddin, 1989), Korea (Choi et al., 2012), Hungary (Kajan et al., 2013), and China (Zhao et al., 2015). Similarly, outbreaks of IBH in broiler chickens caused by FAdVs-8b or -11 have been recorded in Australia, Austria, Spain, and South Africa (Maartens et al., 2014; Schachner et al., 2016; Oliver-Ferrando et al., 2017). During 2012 in Iran, the virus has been demonstrated in an outbreak in a 21-day-old broiler chicken farm with $14 \%$ mortalities (Rahimi and Minoosh, 2015). In addition, two FAdVs- 11 and $-8 b$ (D and E) were related to Iranian outbreaks of IBH that occurred from 2013 to 2016 (Hosseini and Morshed, 2012; Nateghi et al., 2014; Morshed et al., 2017). Moreover, the first case report of isolation and identification of FAdVs-8b from an outbreak of IBH in broiler farms in Turkey was detected by Cizmecigil et al. (2020). Radwan et al. (2019) and ElTholoth and Abou El-Azm (2019) detected the presence of FAdVs-8a (E) in Egyptian broiler chicken flocks, while Elbestawy et al. (2020) have recently isolated 17 strains of FAdVs-2 and -11 (D) from chickens. Mohamed et al. (2018) molecularly characterized FAdVs-2 (D) and -6 (E) as the causative agents of IBH in both broiler chickens and falcon in Saudi Arabia.

It has been suggested that immunosuppressive diseases like infectious bursal disease (Fadly et al., 1976), chicken infectious anemia (Markowski-Grimsrud and Schat, 2003), and Marek's disease (Niczyporuk et al., 2012) may play a role in the transmission of IBH and its increasing mortalities (El-Tholoth and Abou El-Azm, 2019). However, it has been recorded that IBH could induce independent mortalities without the presence of other immunosuppressive factors (Christensen and Saifuddin, 1989; Gomis et al., 2006; Ojkic et al., 2008).

The course of IBH occasionally continues for two to three weeks. In broiler chicken flocks up to five weeks old, the mortality rate of IBH varies from negligible to 5$10 \%$ (McFerran and Smyth, 2000), and may reach 30\% for a short time (average five days) (Alvarado et al., 2007). Very high mortality rates (60-70\%) have been recorded in outbreaks associated with IBH in India and Canada (Dahiya et al., 2002; Gomis et al., 2006, respectively). Some outbreaks have been reported in layers and broiler breeders (McFerran and Adair 2003; Hess, 2013; Schachner et al., 2016). The variable mortalities may be related to the pathogenicity of the virus strain, the host's age and susceptibility, and the presence of concurrent immunosuppressive diseases (Grgic et al., 2011).

In post-mortem lesions, broiler and layer chickens infected with IBH virus revealed swollen, pale, necrotic and friable, and hemorrhagic livers as well as petechial and ecchymotic hemorrhages on the skeletal muscles (McFerran et al., 1976; Mase et al., 2012; Ahamad et al., 2016). Splenomegaly and moderate to severe lymphoid atrophy in the bursa of Fabricius were also recorded in falcons with IBH (Schrenzel et al., 2005). A pale and enlarged pancreas could also be observed (Pilkington et al., 1997). Infection with IBH has been represented in three stages based on the hepatic lesions' severity; the incubation stage (one to three days of infection), the degeneration stage (four to seven days of infection), and 
the convalescence stage (14 days pos-infection) (Steer et al., 2015).

The histopathological examinations of the affected liver with IBH showed variable areas of multifocal hepatocellular necrosis and vacuolar degeneration as well as lymphoid infiltration (Wilson et al., 2010; Schachner et al., 2018). In the degenerated hepatocytes, big, circular, or irregular-shaped intranuclear basophilic inclusion bodies could be detected (Grimes et al., 1977; Steer et al., 2015; Matos et al., 2016). However, acidophilic inclusion bodies that contained few or no virus particles, and corresponded to fibrillary and granular material have also been detected (Itakura et al., 1974). Inclusion bodies could be observed also in the liver, pancreas, and spleen indicating the replication of adenovirus in these organs (Cook, 1983). Matos et al. (2016) recorded that these inclusions could be mostly detected from six to nine days after infection

\section{Hydropericardium syndrome}

Hydropericardium Syndrome (HPS) was first reported in Karachi, Pakistan in 1987 in three to six-weekold broiler chickens (Khawaja et al., 1988), then it was spread in different areas of the country (Anjum et al., 1989; Khan et al., 2005). Several outbreaks of HPS have been recorded in many countries, including India (Dahiya et al., 2002; Rahul et al., 2005; Mittal et al., 2014), Iraq (Abdul-Aziz and Al-Attar, 1991), Hungary (Kajan et al., 2013), Canada (Grgic et al., 2011), Poland (Niczyporuk, 2016), Mexico, Peru, Chile and Ecuador, Russia, Korea (Kim et al., 2008; Choi et al., 2012), China (Liu et al., 2016; Pan et al., 2017b), and Japan (Abe et al., 1998; Mase et al., 2012).

The main causative agent of HPS is FAdVs-4 (C) (Nakamura et al., 2000; Mase et al., 2010; Asthana et al., 2013). Although HPS is a disease of chickens, it has also been detected in ducks, pigeons, and quails in rare cases (Cowen, 1992; Naeem and Akram, 1995; Lobanov et al., 2000). Hydropericardium syndrome is an infectious and highly pathogenic disease that primarily occurs in young broiler chickens (Khawaja et al., 1988; Akhtar, 1994), and is characterized by a low morbidity rate. The mortality rate is variable (Shane, 1996; Mansoor et al., 2011), ranging from $20 \%$ to $75 \%$ (Cheema et al., 1989), 30-80\% (Ahmad et al., 1989; Kumar et al., 1997), or 30-60\% (Zhao et al., 2015) in broiler chickens starting at the third week of age, and peaks for four to eight days. Sometimes, adult broiler breeders could be affected (Asrani et al., 1997) with mortalities reached up to 6.4\% (Abe et al., 1998). Deaths may be due to pericardial effusion, and lung and kidney edema (Niu et al., 2019).
Gross lesions of HPS have been manifested as clear, straw-colored watery or jelly-like fluid in the pericardial sac with the misshapen and flabby heart as well as hemorrhages on the heart muscles and other organs (Asrani et al., 1997; Kumar et al., 1997). Congestion and edema of lungs, enlarged, pale and friable liver, pale kidneys, and swollen bursa of Fabricius have been also observed (Cheema et al., 1989; Ganesh and Raghavan, 2000; Ahmad et al., 2011).

\section{Quail bronchitis}

Quail bronchitis is an acute fatal and highly contagious respiratory disease of young bobwhite quails (Colinus virginianus) with severe economic losses (Barnes, 1987). Chicken Embryo Lethal Orphan Virus (CELOV) virus is an endogenous virus that was isolated from embryonated chicken eggs, and it is similar to QB Virus (QBV) in serological characteristics, in the lesions and death pattern induced in chicken embryos (Yates and Fry, 1957; DuBose and Grumbles, 1959). Accordingly, both QBV and CELOV are considered the same type of strain for group I and serotype 1 of FAdVs (Calnek and Cowen, 1975). Both viruses could cause bronchitis after experimental inoculation in quails (DuBose and Grumbles, 1959). However, neither CELOV nor QBV has been found to induce diseases in species other than quails.

Quail Bronchitis was first detected by Olsen (1950) from an epornitic on a game farm in 1949 in West Virginia, United States. Later on, respiratory diseases have been discovered on quail farms in Taxes (DuBose et al., 1958; DuBose and Grumbles, 1959). The QBV belongs to FAdVs-1 group A (DuBose et al., 1958). In Minnesota, the United States, Singh et al. (2016) reported the isolation and molecular identification of QBV-positive cases from five to eight-week-old bobwhite quails suffering from respiratory signs and lesions as well as elevated mortalities. In the present study, the nucleotide sequences of the four isolates of FAdVs showed $99 \%$ identity with CELO strain of FAdVs group A. In addition, QBV isolates clustered closely with FAdVs group A and were different from FAdV groups B-E and FAdVs of turkeys, ducks, geese, and pigeons.

Captive quail chickens (less than three weeks of age) are severely affected with a morbidity rate approaching $100 \%$ and a mortality rate of more than $50 \%$ (Jack and Reed, 1990). Young chickens and turkeys could be naturally or experimentally infected with QBV without apparent clinical signs (Olsen, 1950; Yates and Fry, 1957). The disease incubation period is about two to seven days. Sudden onset of tracheal rales, coughing, sneezing, and 
high mortalities are the most pronounced signs in the affected quails (DuBose et al., 1958; DuBose, 1967). Swelling of the infraorbital sinuses, conjunctivitis, and other general signs have also been reported (DuBose and Grumbles, 1959). The course of the disease takes one to three weeks (Olsen, 1950). Post-mortem lesions of QBV appear as tracheitis with a severe amount of mucus, lung congestion, fibrinous airsacculitis, liver necrosis, spleen enlargement, and accumulation of urates on the internal organs (Chew-Lim, 1980). Histopathological examination revealed "round-cell" infiltration with follicle formation and intact overlying ciliated epithelium in the trachea with the presence of basophilic intranuclear inclusions in the affected epithelium (Jack and Reed, 1990; Singh et al., 2016). Dhillon et al. (1982) observed leukocytic transmigration and exudation in the bronchi, trachea, and pulmonary parenchyma with diffuse bronchiolitis and pneumonia. Intranuclear inclusion bodies have been seen in the tracheal mucosa two days post-QBV challenge and deciliation and desquamation of epithelium on days four and five post-challenge, respectively (Jack et al., 1994).

\section{Gizzard erosion}

The first detection of gizzard erosion was in 1993 by Tanimura et al. (1993). The main causes of GE are FAdVs-1 (S) and FAdVs-8 (E) as recorded in Japan, England, Italy, Germany, Korea, Poland, and Iran (Manarolla et al., 2009; Grafl et al., 2015), however, experimental infection with other serotypes as FAdVs-4, $8 \mathrm{~b}$, and 11 have been implicated in GE (Okuda et al., 2004; Okuda et al., 2006; Steer et al., 2015). Although the CELO (FAdV-1) strain does not induce GE in chickens (Marek et al., 2010), some strains can induce this lesion in Specific Pathogen Free (SPF) chickens and commercial layer chickens (Ono et al., 2004; Manarolla et al., 2009).

Broiler and layer chickens are the natural host of GE (Tanimura et al., 1993). However, bobwhite quails showed GE in North America (Goodwin, 1993).

Affected gizzards showed variable sizes of brown to black erosion areas (Manarolla et al., 2009). Recently, a post-mortem examination of 48 gizzards collected from seven broiler chicken farms in Iran revealed the presence of perforation, roughening, and discoloration of the koilin layer of gizzard (Mirzazadeh et al., 2019).

Manarolla et al. (2009) demonstrated microscopically multifocal or extensive degeneration of the cuticle's koilin layer with entrapped erythrocytes, ulcers, or sloughing/flattening of glandular epithelium of the gizzards and the presence of heterophils, lymphocytes, macrophages, and plasma cells as well as intranuclear basophilic inclusion bodies. Ono et al. (2003) observed typical microscopic lesions after experimental oral and ocular inoculations of one, three, and five-week-old broiler chickens with FAdV-1 strain. In Korea, experimental oral inoculation of one-week-old SPF chickens with FAdV-1 indicated no signs, but the gizzard showed severe degeneration and necrosis of glandular epitheliums with eosinophilic inclusion bodies in histopathological examination (Lim et al., 2012). Similarly, dissociation of cellular debris in the koilin layer, mild to severe inflammatory cells infiltration of the mucosa, submucosa, and musculosa with inflammatory cells as well as desquamation of epithelial cells in the glandular mucosa (Mirzazadeh et al., 2019).

\section{Turkey hemorrhagic enteritis}

Turkey Hemorrhagic Enteritis (THE) is a viral disease in turkeys characterized by acute signs of depression, bloody diarrhea, increased mortalities, and transient immunosuppression (Saif, 1998; Hoerr, 2010). The disease causes severe economic losses due to acute sudden deaths up to $80 \%$, blood loss, and anemia as well as immuno-suppression with secondary bacterial or parasitic infections in sub-clinical conditions (Chandra and Kumar, 1998; Koncicki et al., 2012). This immunosuppression is expressed by decreasing the immune response to various vaccines as Newcastle disease (Nagaraja et al., 1985) and Metapneumo viruses vaccines (Chary et al., 2002).

The first distinguishing of THE was earlier in the USA without the identification of the exact causative agent (Pomeroy and Fenstermacher, 1937; Gale and Wyne, 1957). After that, the researchers supposed that the cause of THE could be filtrated through a 0.22-micron filter (Gross and Moore, 1967), and that result proved that the cause of THE is a virus (Domermuth and Gross, 1971). In 1974, adeno-like virus particles were detected in the spleen and intestine of the affected turkeys (Carlson et al., 1974). Then, THE has been discovered in different parts all over the world as Canada (Itakura et al., 1974), Japan (Fujiwara et al., 1975), England (Arbuckle et al., 1979), Australia (Tham and Critchley, 1981), the USA (Ianconescu et al., 1985) and Spain (Gomez-Villamandos et al., 1994).

The THE virus (THEV) is postulated as siadenovirus A, a member of the family Adenoviridae, genus Siadenovirus (Pierson and Fitzgerald, 2013). The results of molecular characterization of hexon gene revealed that the THEV is related to FAdV-3 which is closely related to that of penguin adenovirus (Lee et al., 2016). However, data 
about the phylogenetic analysis and the sequence data of THEV are limited and scarce. The same virus was related to three to eight months old pheasants with MSD (Fitzgerald and Reed, 1989) and avian adenovirus splenomegaly in broiler chickens. This virus is serologically indistinguishable from THEV with diversity only at the genomic level.

Although turkey is the natural susceptible host, antibodies against THDV have been found in other species as chickens (Domermuth et al., 1979), quails, peafowl, and chukars (McFerran and Smyth, 2000). The disease is more pronounced in six to 11 weeks old turkeys. Birds younger than four weeks old are less susceptible which may be due to the presence of maternal antibodies that protect turkeys in the first week of life (Fadly and Nazerian, 1984).

Following entering of THEV to the body of the bird, the virus multiplies in the gastrointestinal tract, then migrates to the blood inducing primary viremia, and spreads to some immune organs like the spleen and bursa of Fabricius where Immunoglobulin (Ig) $\mathrm{M}$ bearing Blymphocytes (Rautenschlein et al., 1998). So, THEV is regarded as a lymphotropic and lymphocytopathic (Fitzgerald and Reed, 1991) as well as macrophages target the virus (Suresh and Sharma, 1995). In the stage of transient immunosuppression, there is a reduction in antibody production and phagocytosis process, as well as the release of prostaglandins and histamine by mast cells (Rautenschlein, 2000). Due to the presence of a high level of the virus in the intestine, intestinal congestion and hemorrhages can be observed (Hussain et al., 1993; Dhama et al., 2017).

Affected turkeys with THE manifest general signs with severe bloody diarrhea as the skin and feathers around the vent are soaked with blood. Deaths usually occur five to six days after the onset of bloody diarrhea. The mortality rate may reach up to $60 \%$ (Pomeroy and Fenstermacher, 1937; Gale and Wyne, 1957). Signs usually subside within five to 10 days post-infection, and survived turkeys show permanent immunosuppression. Recovered birds from THE may show persistent infection, and become chronic carriers (Beach et al., 2009). In addition, these birds become highly susceptible to secondary diseases like colibacillosis, bordetellosis, mycoplasmosis, clostridia, turkey rhinotracheitis, and coccidiosis (Giovanardi et al., 2014). Avirulent strains of THEV can enhance sub-clinical infections inducing strong immunosuppression and losses due to secondary infections (Tykałowski and Koncicki, 2017; Tykałowski et al., 2019).
Dead birds show severe hemorrhagic enteritis and typhlitis with the pale anemic carcass. The gastrointestinal tracts of turkeys are severely distended with blood (Gross and Moore, 1967). The lesions of the intestines consist of congestion, petechial hemorrhages, and sometimes the presence of the fibrino-diphtheritic membrane. Other characteristic lesions like severely enlarged and mottled or marbled spleen (Itakura and Carlson, 1975; Cobb and Smith, 2015), congested lungs, enlarged liver, and petechial hemorrhages all over the organs are also recorded.

\section{Egg drop syndrome}

The first description of a syndrome causing low egg production and soft-shelled or shellless eggs in a laying fowl flock was in the Netherlands in 1967 (Van Eck et al., 1976). In Northern Ireland, haemagglutinating FAdVs were isolated from laying hens (McFerran et al., 1977; McFerran et al., 1978; McCraken and McFerran, 1978). Later, the disease has been termed Egg Drop Syndrome (EDS) and discovered in many countries all over the world (Firth et al., 1981; Lu et al., 1985). However, antibodies against the EDS virus (EDSV) have been detected in chickens in Denmark, Brazil, Mexico, Nigeria, and New Zealand (Nawathe and Abegunde, 1980; Howell, 1982).

It has been recorded that EDSV is designated as duck adenovirus 1 belonging to Atadenovirus genus of the Adenoviridae family (Hess et al., 1997; Dán et al., 1998). Recently, FAdVs-4 has been molecularly detected and isolated from the oviduct of layer chicken flocks with poor egg production in Eastern Japan (Del Valle et al., 2020).

Although waterfowl as ducks and geese are the most common natural hosts for EDSV infections (Schlör, 1980; Zsak et al., 1982; Bartha and Mészáros, 1984). Turkeys can get the infection with ESDV after an experimental infection (Parsons et al., 1980) but without clinical signs. Besides, antibodies against EDSV have been found in wild birds (Malkinson and Weisman, 1980), wild waterfowl (Schlör, 1980; Gulka et al., 1984), and pigeons (Durojaiye et al., 1992). Pheasants, guinea fowls, and quails can take the infection from infected chicken flocks, and transmit it by contact.

Outbreaks of EDS are characterized by a drop in egg production up to $50 \%$, and last for four to 10 weeks (Van Eck et al., 1976; McFerran et al., 1978; Alam et al., 2009). In Japan, Yamaguchi et al. (1981) reported the first outbreak of EDS in a 30-55 weeks old broiler breeder farm with a $20-25 \%$ fall in egg production that continued for three to seven weeks. However, Alam et al. (2009) and Biswas et al. (2009), in Bangladesh, detected seropositive 
cases of EDSV in layer flocks showing a decrease in egg production and soft-shelled or shell-less eggs. Furthermore, McFerran and Adair (2003) demonstrated that EDS usually happens when egg production is between $50 \%$ to the peak level and lasts for four to 10 weeks with a $40 \%$ drop in egg production. Infected quail flocks showed a fall in egg production, an increase in the number of softshelled eggs as well as a development of haeminhibiting antibodies to EDSV (Das and Pradhan, 1992). The respiratory manifestation was also reported in goslings EDSV (Ivanics et al., 2001).

The main site for the virus replication is the eggshell gland region of the oviduct causing oedema (Taniguchi et al., 1981; Lu et al., 1985), consequently, abnormal eggs are produced (Smyth et al., 1988). Abnormal external egg quality in the form of discoloration and soft thin or shellless eggs are common in cases of EDS infection (Yamaguchi et al., 1981). Moreover, deterioration of the internal egg quality can be affected by the virus as an adverse effect on albumin quality could be observed (Cook and Darbyshire, 1981). Only slight diarrhea could be detected after natural or experimental infection with the virus (Higashihara et al., 1987).

\section{Diagnosis of fowl adenoviruses}

Clinical diagnosis based on the observation of specific signs and lesions is difficult and nonconfirmative. Microscopic detection of specific lesions, as well as inclusion bodies, may be diagnostic for FAdVs infections (Anjum et al., 1989). Electron microscopy is successfully used for the detection of the virus morphology after staining of tissue homogenates (Cheema et al., 1989; Chandra et al., 1997; Ganesh et al., 2002).

The laboratory diagnosis of FAdVs infections is based on the use of recent conventional and molecular techniques for virus detection. Fowl adenoviruses could be propagated in the yolk sac or chorioallantoic membrane of embryonated chicken eggs as well as duck eggs. Inoculated embryos showed deaths, stunted growth, curling, and hemorrhages as well as the presence of inclusion bodies in their tissues. The virus can cause latent infection of the embryos till hatching indicated infections in the next generation of birds (Fadly and Winterfield, 1973; McFerran and Adair, 1977; Toro et al., 2001). The type and species of birds vary according to the type of the inoculated eggs (chickens, turkeys, and ducks). This type of latent infection has been recorded as FAdVs-1 (Grgić et al., 2006).

Homogenates of 11 or 19 days old FAdVs infected chicken embryos could be successfully inoculated on tissue culture lines (Chandra et al., 2000; Balamurugan et al., 2002; Ahmad et al., 2011). These viruses are propagated on the chicken embryo, liver, kidney, fibroblast, and Vero cell lines with positive reaction (areas of cytopathic effects) that appeared within five to six days. The cytopathic effect appears as detachment of the cell surface with the presence of inclusion bodies (Khawaja et al., 1988). Sometimes, these viruses require adaptation by serial passages on cell lines to induce cytopathic effects (Roy et al., 2001). However, some research failed in the propagation of the viruses on tissue culture like the Japanese quail fibrosarcoma cell line (QT 35) (Afzal and Ahmad, 1990).

It has been documented that FAdVs could be easily detected using virus isolation and real-time PCR rather than using conventional Polymerase Chain Reaction (PCR) (Günes et al., 2012). Nowadays, it is molecular techniques are commonly used for viral genes. Diagnosis of FAdVs is based on the detection of the hexon gene loop 1 (Hex L1) of a major capsid protein gene using PCR (Xie et al., 1999; Raue et al., 2005; Mase et al., 2009). Hexon gene is amplified at the 700-bp fragment and is used as a probe for the dot blot hybridization technique (Ganesh et al., 2002). In addition, sequencing of the DNA-dependent polymerase gene or detection of $52 \mathrm{~K}$ gene has also been used for detection of FAdVs (Kajan et al., 2011; Günes et al., 2012; Kajan et al., 2013). Differentiation of FAdVs to different species and serotypes could be carried out through amplification of specific regions on hexon gene, and then specify the product using restriction enzyme digestion or nucleotide sequencing (Meulemans et al., 2001). Moreover, serotyping of FAdVs is based on the presence of neutralizing epitope in the hexon gen which is serotype-specific (Hess, 2000; Russell, 2009; Liu et al., 2016; Niczyporuk, 2016).

Restriction Fragment Length Polymorphism (RFLP) grouped FAdVs into five diverse species (A-E) (Hess, 2000), and used HpaI enzymes for the digestion of the PCR product (Raue and Hess, 1998). To distinguish various FAdVs-4 strains, PCR-RFLP analysis of the short fiber gene using the enzyme AluI was useful (Mase et al., 2010).

Detection of antibodies against FAdVs has been applied using some serological methods like agar gel precipitation test, enzyme-linked immunosorbent assay, haemagglutination assay for rat and rhesus erythrocytes, dot immunobinding assay, immunoperoxidase test, and virus neutralization test (Saifuddin and Wilks, 1990; Manzoor and Hussain, 2003). Using serological tests may face some obstacles like the presence of antibodies in both 
healthy and diseased birds (Hafez, 2011; Thakor et al., 2012).

\section{Prevention and control of fowl adenoviruses}

Reducing the incidence of FAdVs infections can be based on maintaining good management and husbandry practices. Thorough cleaning and disinfection, strict biosecurity measures as well as proper ventilation may significantly reduce the chances of infection (Poss, 1998). Reducing the movement of visitors, wearing special clothes and footwear, and shower-in-and-shower-out facilities are advised in breeder farms. Prevention of mechanical transmission of infections through efficient eradication of rodent and insects are also suggested. A concentration of $0.07-0.1 \%$ iodophor solution in the drinking water proved efficiency against FAdVs (AbdulAziz and Al-Attar, 1991; Abdul-Aziz and Hassan, 1995). Antibiotics could be used in a case of infection to avoid secondary bacterial infection. Suppling birds with vitamins and minerals to improve immunity is also important. In case of THEV infection, passive protection of turkey poults with antiserum of recovered flocks has been studied. Recovered turkeys from THEV infection showed persistent immunity, accordingly, antibodies in the serum of these birds could be used for the protection of unvaccinated young turkeys. Infections with different forms of FAdVs resulting from shortages in the application of hygienic and biosecurity measures in the farms (Elbestawy et al., 2020).

Vaccine administration is essential to combat FAdVs infections. Three types of vaccines including inactivated whole-cell live attenuated, and recombinant vaccines have been developed against the different forms of such infections (Shah et al., 2017). In areas where the adenovirus infections are endemic, FAdVs infections have been controlled using formalin-inactivated cell culture and live vaccines (Schachner et al., 2016; Schachner et al., 2018). These vaccines proved efficacy against natural and experimental FAdVs infections, and significantly reduced mortality (Balamurugan and Kataria, 2004). The protection level of the prepared vaccines was estimated based on the reduction of the severity of clinical signs, mortality rate, post-mortem lesions in the organs, and the characteristics of histopathological findings (Mansoor et al., 2011).

It has been proved that inactivated cell culture vaccine type is easier and faster in preparation than other types and effectively controlled FAdVs infections (Chandra et al., 2000; Kim et al., 2014). An inactivated liver homogenate vaccine was successfully used for the prevention of HPS (Chishti et al., 1989; Akhtar et al., 2000; Ahmad and Hassan, 2004). The studies of Ahmad et al. (1990) proved that vaccination of broiler chickens at 15-18 days old was more effective than vaccination at 1012 days of age to give vaccination to give the best protection against HPS. Subcutaneous inoculations of inactivated liver homogenate or cell culture vaccines for 10-15 days old broiler chickens have been found to bring HPS under the control in terms of reduction of mortalities (Chandra et al., 2000). In comparison with the inactivated liver homogenate vaccine, a living egg-adapted attenuated vaccine against HPS infection was prepared (Mansoor et al., 2011). The results showed higher antibody titters in broiler chickens that were immunized orally or parentally with a sixteenth-passage attenuated virus at 7, 14, and 21 days post-immunization with a protection rate reaching 95\% compared with the only $55 \%$ in liver homogenate vaccine.

In Peru, the oil-adjuvanted cell culture IBH vaccine provided better protection to the vaccinated birds in comparison with the autogenous vaccine. Moreover, inactivated oil emulsion cell culture FAdVs-4 vaccines induced serotype homologous and heterologous crossprotection for the vaccinated breeders as well as their progeny (Kim et al., 2014). In China, a strain of FAdVs-4 was used for the preparation of inactivated oil-emulsion vaccine, and the results showed that a single dose was effective, and gave good protection against homologous virulent FAdVs-4 and heterologous virulent FAdVs- $8 \mathrm{~b}$ strains challenges (Xia et al., 2017). However, in Pakistan, Khan et al. (2005) and Mahmood et al. (2011) demonstrated outbreaks of the disease after vaccination, so they recommended propagation of the virus on SPF embryonated eggs and cell cultures to produce killed and live attenuated vaccines.

Earlier, Fadly and Nazerian (1984) demonstrated that THEV vaccines prepared by propagation in turkey origin Marek's disease which produced B-lymphoblastoid cell line have elicited effective protection against THEV without adverse effects. Maternal immunity can protect turkey poults against THEV infections in the first weeks of life, and also can interfere with vaccination protocols. But, earlier vaccination is very important to prevent exposure to virulent field THEV strains. Some vaccines have been produced from avirulent THEV strains after propagation in turkeys' leukocytes culture (Van den Hurk, 1990), and they are taken either 18-19-day-old embryos (in-ovo vaccination) or for three to six-week-old turkey poults through drinking water route. Vaccinated birds by these types of vaccines need a booster dose to gain complete 
protection. Cell culture lives vaccines prepared from avirulent strains of THEV or MSD virus could be effectively used to control the infections (Fadly et al., 1985; Sharma, 1994).

Live vaccines of THEV are prepared either by mixing of 6-week-old turkeys' splenic homogenates with avirulent THEV isolate or by inoculation of RP19 cell cultures. However, cell culture-prepared vaccines are only commercially available. Barbour et al. (1993) found that cell culture liquid vaccines are more effective than frozen ones in provoking seroconversion and antigen clearance from splenic tissue. Vaccinated birds showing more than $60 \%$ seroconversion with splenic homogenate indicate good protection. Good protection could be obtained if the inoculated splenic homogenates vaccines give more than $60 \%$ seroconversion rate in the vaccinated birds.

In addition to the traditionally used vaccine, other types of recombinant vaccines like hexon protein-based subunit or virus-vectored vaccines using fowl poxvirus expressing the native hexon of THEV have been developed (Cardona et al., 1999). This monoclonal vaccine does not associate with any immunosuppression. The containing protein of this vaccine should not be denatured, and also it should retain its native structure to give the desired results

The recombinant fowl poxvirus vaccine should coexpress the hexon and a $100 \mathrm{kDa}$ folding protein to elicit the best humoral immune response (Cardona et al., 2001). Another type of THEV sub-unit vaccine has been produced from capsid protein (knob protein) of THEV expressed in Escherichia coli (Pitcovski et al., 2005). This type of vaccine also showed safety, efficacy, and adequate protection against the THEV challenge. Rautenschlein and Sharma (1999) demonstrated that a combined vaccine of THEV and Newcastle disease virus failed to induce protection against both infections.

Commercially, three types of vaccines are used to prevent THE worldwide, the first type is live autogenous "splenic" vaccines, the second type includes live, tissue culture-derived vaccines, and the third type encompasses inactivated vaccines (Giovanardi et al., 2014). In comparison with tissue culture-derived vaccine, the splenic vaccine is considered more potent and requires fewer revaccinations to induce protective immunity (Weier, 2013). The tissue culture vaccine for THE is used to control infection in Canada, and it may be applied once at 3.5 to six weeks of age, or twice at 25 and 35 days of age. Passive or maternal immunity is transferred from vaccinated turkey breeder hens to their progeny to protect the poults for the first two to three weeks of life (Weier,
2013). The severity of clinical signs of THEV decreased due to vaccination and the circulation of avirulent virus strains in the field (Giovanardi et al., 2014). In a recent study by Palomino-Tapia et al. (2020), in Canada, the researchers found circulation of wild-type THEV in vaccinated flocks, so they developed a novel procedure that allows whole-genome sequencing of THEV from spleens, without passaging in cell culture or passaging in vivo.

Recombinant or sub-unit vaccine has been developed to overcome FAdVs infections. The effectiveness of this type of vaccine against EDSV in chickens (Fingerut et al., 2003), THEV (Pitcovski et al., 2005), and HPS virus in broiler chickens (Shah et al., 2012) have been determined. In the recombinant vaccine of HPS, the penton base protein of the FAdVs-4 was cloned and expressed in Escherichia coli in chickens, as it conferred a protection rate of $90 \%$ after the viral challenge. In addition, the role of fiber proteins type 1 and 2 was also tested as a candidate for the preparation of subunit vaccine (Schachner et al., 2014), and the results revealed that the recombinant fiber- 2 was protective against signs but not the viral fecal excretion. The subunit vaccine is recommended over other types due to the elimination of the outbreaks caused by incomplete attenuation or inactivation (Fingerut et al., 2003). Moreover, the application of modern practices of recombinant DNA technology should be essential for the diagnosis and prevention of FAdVs infections (Balamurugan and Kataria, 2004; Khan et al., 2005).

\section{CONCLUSION}

Further surveillance studies on FAdVs affections in different avian species as well as the geographic distribution of these viruses in different regions all over the world should be given into consideration. In addition, the pathogenicity of the FAdVs strains and their potential risks are needed. Researches regarding the preparation and production of FAdVs vaccines should be regularly updated to overcome such infections.

\section{DECLARATIONS}

\section{Competing interests}

The author has not declared any conflict of interest.

\section{Ethical considerations}

Plagiarism, consent to publish, misconduct, data

fabrication and/or falsification, double publication and/or 
submission, and redundancy have been checked by the author.

\section{REFERENCES}

Abdul-Aziz TA, and Al-Attar MA (1991). New syndrome in Iraqi chicks. Veterinary Record, 129: Article number 272. DOI: https://www.doi.org/10.1136/vr.129.12.272

Abdul-Aziz TA, and Hassan SY (1995). Hydropericardium syndrome in broiler chickens: its contagious nature and pathology. Research in Veterinary Science, 59: 219-221. DOI: https://www.doi.org/10.1016/00345288(95)90005-5

Abe T, Nakamura K, Tojo H, Mase M, Shibahara T, Ya S, Aguchi A, and Yuasa N (1998). Histology, immunohistochemistry, and ultrastructure of hydropericardium syndrome in adult broiler breeders and broiler chicks. Avian Diseases, 42: 606-612. DOI: https://www.doi.org/10.2307/1592690

Absalón AE, Morales-Garzón A, Vera-Hernández PF, Cortés-Espinosa DV, UribeOchoa SM, García LJ, and Lucio-Decanini E (2017). Complete genome sequence of a non-pathogenic strain of Fowl Adenovirus serotype 11: Minimal genomic differences between pathogenic and nonpathogenic viruses. Virology, 501: 63-69. DOI: https://www.doi.org/10.1016/j.virol.2016.11.006

Afzal M, and Ahmad I (1990). Efficacy of an inactivated vaccine against hydropericardium syndrome in broilers. Veterinary Record, 126: 59-60. PMID: 2301129.

Ahamad DB, Selvaraj J, Sasikala M, and BabuPrasath N (2016). Inclusion body hepatitis in chicken. Indian Veterinary Journal, 93: 34-35. Available at: http://www.ivj.org.in/downloads/336862pg\%2034-35.pdf

Ahmad K, and Hassan S (2004). The efficacy of experimental Angara disease vaccines. Pakistan Veterinary Journal, 24: 101-104. Available at: http://www.pvj.com.pk/pdf-files/24_2/101-103.pdf

Ahmad I, Afzal M, Malik MI, Hussain Z, and Hanif W (1989). Studies on the disease pattern and etiology of hydropericardium syndrome (Angara disease) in broiler chickens in Pakistan. Pakistan Journal of Agricultural Research, 10: 195-199. DOI: https://www.doi.org/10.1136/vr.128.25.591

Ahmad I, Malik MI, Iqbal K, Ahmad K, and Naz S (1990). Efficacy of formalized liver organ vaccine against Angara disease in broilers. Veterinarski Arkhiv, 60: 131-138. Avialable https://www.cabdirect.org/cabdirect/abstract/19912218752

Ahmad MD, Zaman S, Mushtaq MH, Anjum AA, and Akram M (2011). Comparative pathogenicity of liver homogenate and cell culture propagated hydropericardium syndrome virus in broiler birds. Pakistan Veterinary Journal, 31(4): 321-326. Available at: https://agris.fao.org/agrissearch/search.do?recordID=DJ2012067162

Akhtar S (1994). Hydropericardium syndrome in broiler chickens in Pakistan. World's Poultry Science Journal, 50: 177-182. DOI: https://www.doi.org/10.1079/WPS19940015

Akhtar M, Ahmad R, Hayat CS, Hussain I, and Ashfaque M (2000). Comparative immune response of formalin inactivated and binary ethyleneimine inactivated Angara disease vaccines. Pakistan Journal of Biological Science, 3: 1313-1314. DOI: https://www.dx.doi.org/10.3923/pjbs.2000.1313.1314

Alam J, Al-Mamun M, Samad MA, Ullah MR, Giasuddin M, and Taimur M (2009). Outbreak of egg drop syndrome in Bangladesh. International Journal of Biology, 1: 56-64. DOI: https://www.doi.org/10.5539/ijb.v1n1p56

Alvarado IR, Villegas P, El-Attrache J, Jensen E, Rosales G, Perozo F, and Purvis LB (2007). Genetic characterization, pathogenicity, and protection studies with an avian adenovirus isolate associated with inclusion body hepatitis. Avian Diseases, 51: 27-32. DOI: https://www.doi.org/10.1637/00052086(2007)051[0027:gcpaps]2.0.co;2

Anjum AD, Sabri MA, and Iqbal Z (1989). Hydropericarditis syndrome in broiler chickens in Pakistan. Veterinary Record, 124: 247-248. DOI: https://www.doi.org/10.1136/vr.124.10.247

Arbuckle JBR, Parsons DG, and Luff PR (1979). Hemorrhagic enteritis syndrome of turkeys. Veterinary Record, 104: 435-436. DOI: https://www.doi.org/10.1136/vr.104.19.435

Asrani RK, Gupta BK, Sharma SK, Singh SP, and Katoch RC (1997). Hydropericardium hepatopathy syndrome in Asian poultry. Veterinary Record, 141: 271-273. DOI: https://www.doi.org/10.1136/vr.141.11.271

Asthana M, Chandra R, and Kumar R (2013). Hydropericardium syndrome: current state and future developments. The Archives of Virology, 158: 921-931. DOI: https://www.doi.org/10.1007/s00705-012-1570-x

Balamurugan V, and Kataria JM (2004). The hydropericardium syndrome in poultry - a current scenario. Veterinary Research Communication, 28: 127-148. DOI: https://doi.org/10.1023/B:VERC.0000012115.86894.1e
Balamurugan V, Kataria JM, Kataria RS, Verma KC, and Nanthakumar T (2002). Characterization of fowl adenovirus 4 associated with hydropericardium syndrome in chicken. Comparative Immunology, Microbiology and Infectious Diseases, 25: 139-147. DOI: https://www.doi.org/10.1016/S01479571(01)00032-7

Barbour EK, Poss PE, Brinton MK, Johnson JB, and Nabbut NH (1993). Evaluation of cell culture propagated and in vivo propagated hemorrhagic enteritis vaccines in turkeys. Veterinary Immunology and Immunopathology, 35: 375383. DOI: https://www.doi.org/10.1016/0165-2427(93)90046-7

Barnes HJ (1987). Diseases of quail. Veterinary Clinics of North America: Small Animal Practice, 17: 1109-1144. DOI: https://www.doi.org/10.1016/s01955616(87)50107-3

Bartha A, and Mészáros J (1984). Experimental infection of laying hens with an adenovirus isolated from ducks showing EDS symptoms. Acta Veterinaria Hungarica, 33: 125-127. PMID: $\underline{3012988}$

Beach NM, Duncan R, Larsen C, Meng XJ, Sriranganathan N, and Pierson F (2009). Persistent infection of turkeys with an avirulent strain of turkey hemorrhagic enteritis virus. Avian Diseases Digest, 4: 370-375. DOI: https://www.doi.org/10.1637/8972.

Benko M, and Harrach B (2003). Molecular evolution of adenoviruses. Current Topics in Microbiology and Immunology, 272: 33-35. DOI: https://www.doi.org/10.1007/978-3-662-05597-7_1

Biswas PK, Barua H, Uddin GM, Biswas D, Ahad A, and Debnath NC (2009). Serosurvey of five viruses in chickens on smallholdings in Bangladesh. Preventive Veterinary Medicine, 88(1): 67-71. DOI: https://www.doi.org/10.1016/i.prevetmed.2008.06.018

Blicharz KD, Tomczyk G, Smietanka K, Kozaczynski W, and Minta Z (2011). Molecular characterization of fowl adenoviruses isolated from chickens with gizzard erosions. Poultry Science, 90: 983-989. DOI: https://www.doi.org/10.3382/ps.2010-01214

Bradley GA, Shupe MR, Reggiardo C, Noon TH, Lozano-Alarcon F, and Bicknell EJ (1994). Inclusion body hepatitis in Gambel's quail (Callipepla gambelii). Journal of Wildlife Diseases, 30(2): 281-284. DOI: https://doi.org/10.7589/0090-3558-30.2.281

Burnett RM (1985). The structure of the adenovirus capsid. II. The packing symmetry of hexon and its implications for viral architecture. Journal of Molecular Biology, 185: 125-143. DOI: https://www.doi.org/10.1016/0022$\underline{2836(85) 90187-1}$

Calnek BW, and Cowen BS (1975). Adenoviruses of chickens: serologic groups. Avian Diseases, 19: 91-103. DOI: https://www.doi:10.2307/1588959

Cardona CJ, Reed WM, Witter RL, and Silva RF (1999). Protection of turkeys from hemorrhagic enteritis with a recombinant fowl poxvirus expressing the native hexon of hemorrhagic enteritis virus. Avian Diseases, 43(2): 234-244. DOI: https://www.doi.org/10.2307/1592613

Cardona CJ, Nazerian K, Reed WM, and Silva RF (2001). Characterization of a recombinant fowlpox virus expressing the native hexon of hemorrhagic enteritis virus. Virus Genes, 22: 353-361. DOI: https://www.doi.org/10.1023/A:1011134811271

Carlson H, Al-Sheikhly F, Pettit J, and Seawright G (1974). Virus particles in spleens and intestines of turkeys with hemorrhagic enteritis. Avian Diseases, 18: 67-73. DOI: https://www.doi:10.2307/1589243.

Chandra R, Shukla SK, and Kumar M (2000). The hydropericardium syndrome and inclusion body hepatitis in domestic fowl. Tropical Animal Health and Production, 32: 99-111. DOI: https://www.doi.org/10.1023/A:1005230703093

Chandra R, Shukla SK, Kumar M, and Garg SK (1997). Electron microscopic demonstration of an adenovirus in the hepatocytes of birds experimentally infected with hydropericardium syndrome. Veterinary Record, 140: 70-71. DOI: https://www.doi.org/10.1136/vr.140.3.70-b

Chandra R, and Kumar A (1998). Haemorrhagic enteritis of turkeys and related infections of pheasants and domestic fowl: A review. World's Poultry Science Journal, 54: 253-269. DOI: https://www.doi.org/10.1079/WPS19980017

Chary P, Rautenschlein S, and Sharma JM (2002). Reduced efficacy of hemorrhagic enteritis virus vaccine in turkeys exposed to avian pneumovirus. Avian Diseases, 46: 353-359. Available at: http://www.jstor.org/stable/1592828

Cheema AH, Ahmad J, and Afzal M (1989). An adenovirus infection of poultry in Pakistan. Revue Scientifique et Technique de l'Office International des Epizooties, 8: 789-795. Available at: https://www.oie.int/doc/ged/D8367.PDF

Chew-Lim M (1980). Adult Coturnix quail bronchitis. Avian Diseases, 24: 520-526. DOI: https://www.doi.org/10.2307/1589724.

Chishti MA, Afzal M, and Cheema AH (1989). Preliminary studies of the development of vaccine against the hydropericardium syndrome. Revue 
Scientifique et Technique de l'Office International des Epizooties, 8: 797 801. Available at: https://www.oie.int/doc/ged/d9404.pdf

Choi KS, Kye SJ, Kim JY, Jeon WJ, Lee EK, Park KY, and Sung HW (2012). Epidemiological investigation of outbreaks of fowl adenovirus infection in commercial chickens in Korea. Poultry Science, 91: 2502-2506. DOI: https://www.doi.org/10.3382/ps.2012-02296

Christensen NH, and Saifuddin M (1989). A primary epidemic of inclusion body hepatitis in broilers. Avian Diseases, 33(4): 622-630. DOI: https://www.doi.org/10.2307/1591135.

Cizmecigil UY, Umar S, Yilmaz A, Bayraktar E, Turan N, Tali B, Aydin O, Tali HE, Yaramanoglu M, Yilmaz SG et al. (2020). Characterisation of fowl adenovirus (FAdV-8b) strain Concerning the geographic analysis and pathological lesions associated with inclusion body hepatitis in broiler flocks in turkey. Journal of Veterinary Research, 64(2): 231-237. DOI: https://www.dx.doi.org/10.2478\%2Fivetres-2020-0026

Cobb S, and Smith H (2015). The spread of non-OIE-listed avian diseases through international trade of chicken meat: an assessment of the risks to New Zealand. Revue Scientifique et Technique (International Office of Epizootics), 34: 795-812. DOI: https://www.doi.org/10.20506/rst.34.3.2396

Cook JK (1983). Fowl adenoviruses: studies on aspects of the pathogenicity of six strains for 1-day-old chicks. Avian Pathology, 12: 35-43. DOI: https://www.doi.org/10.1080/03079458308436147

Cook JK, and Darbyshire J (1981). Longitudinal studies on the egg drop syndrome 1976 (eds-76) in the fowl following experimental infection at 1-day-old. Avian Pathology, 10: 449-459. DOI: https://www.doi.org/10.1080/03079458108418495

Cowen S (1992). Inclusion body hepatitis-anaemia and hydropericardium syndrome; aetiology and control. World's Poultry Science Journal, 48: 247253. DOI: https://www.doi.org/10.1079/WPS19920019

Dahiya S, Srivastava RN, Hess M, and Gulati BR (2002). Fowl adenovirus serotype 4 associated with outbreaks of infectious hydropericardium in Haryana, India. Avian Diseases, 46: 230-233. Available at: http://www.jstor.org/stable/1592810

Dán A, Ruzsics Z, Russell WC, Benkő M, and Harrach B (1998). Analysis of the hexon gene sequence of bovine adenovirus type 4 provides further support for a new adenovirus genus (Atadenovirus). Journal of General Virology, 79: 1453-1460. DOI: https://www.doi.org/10.1099/0022-1317-79-6-1453

Das BB, and Pradhan HK (1992). Outbreaks of egg drop syndrome due to EDS-76 virus in quail (Coturnix coturnix japonica). Veterinary Record, 131: 264-265. DOI: https://www.doi.org/10.1136/vr.131.12.264

Davison AJ, Benko M, and Harrach B (2003). Genetic content and evolution of adenoviruses. Journal of General Virology, 84(11): 2895-2908. DOI: https://www.doi.org/10.1099/vir.0.19497-0

Del Valle FP, Camba SI, Umali DV, Sasai K, Shirota K, Katoh H, and Tajima T (2020). Research note: Molecular and pathologic characterization of avian adenovirus isolated from the oviducts of laying hens in eastern Japan. Poultry Science, 99 : 5: 2459-2468. https://www.doi.org/10.1016/j.psj.2019.12.059

Dhama K, Gowthaman V, Karthik K, Tiwari R, Sachan S, Kumar MA, Munuswamy P, Malik YS, Singh RK, and Munir M (2017). Haemorrhagic enteritis of turkeys-Current knowledge. Veterinary Quarterly, 37: 31-42. DOI: https://www.doi.org/10.1080/01652176.2016.1277281

Dhillon AS, Winterfield RW, Thacker HL, and Feldman DS (1982). Lesions induced in the respiratory tract of chickens by serologically different adenoviruses. Avian Diseases, 26: 478-486. DOI: https://www.doi.org/10.2307/1589893

Domermuth CH, and Gross WB (1971). Effect of disinfectants and drying on the virus of hemorrhagic enteritis of turkeys. Avian Diseases, 15: 94-97. DOI: https://www.doi.org/10.2307/1588392

Domermuth $\mathrm{CH}$, and Gross WB (1972). Effect of chlorine on the virus of hemorrhagic enteritis of turkeys. Avian Diseases, 16: 952-953. PMID: $\underline{4628023}$.

Domermuth CH, Harris JR, Gross WB, and Dubose RT (1979). A naturally occurring infection of chickens with a hemorrhagic enteritis/marble spleen disease type of virus. Avian Diseases, 23: 479-484. DOI: https://www.doi.org/10.2307/1589578

Domermuth CH, Weston CR, Cowen BS, Colwell WM, Gross WB, and DuBose RT (1980). Incidence and distribution of avian adenovirus group II splenomegaly of chickens. Avian Disease, 24: 591-594. DOI: https://www.doi.org/10.2307/1589794

DuBose RT (1967). Quail bronchitis. Bulletin of Wildlife Disease Association, 3: 10-13. DOI: https://www.doi.org/10.7589/0090-3558-3.1.10
DuBose RT, and Grumbles LC (1959). The relationship between quail bronchitis virus and chicken embryo lethal orphan virus. Avian Diseases, 3: 321-344. DOI: https://www.doi.org/10.2307/1587679.

DuBose RT, Grumbles LC, and Flowers AI (1958). The isolation of nonbacterial agent from quail with a respiratory disease. Poultry Science, 37: 654-658. DOI: https://www.doi.org/10.3382/ps.0370654

Durojaiye OA, Ahmed AS, and Adene DF (1992). Egg drop syndrome ' 76 in poultry and other avian species in Nigeria. Revue d Elevage et de Medecine Veterinaire des Pays Tropica, 44: 37-38. PMID: 1775687.

Elbestawy AR, Ibrahim M, Hammam H, Noreldin AE, El Bahrawy A, and Ellakany HF (2020). Molecular characterization of fowl adenovirus D species in broiler chickens with inclusion body hepatitis in Egypt. Alexandria Journal of Veterinary Sciences, 64(1): 110-117. http://www.dx.doi.org/10.5455/ajvs.74411

El-Tholoth M, and Abou El-Azm KI (2019). Molecular detection and characterization of fowl adenovirus associated with inclusion body hepatitis from broiler chickens in Egypt. Tropical Animal Health and Production, 51: 1065-1071. DOI: https://www.doi.org/10.1007/s11250-018-01783-0

Erny KM, Barr DA, and Fahey KJ (1991). Molecular characterization of highly virulent fowl adenoviruses associated with outbreaks of inclusion body hepatitis. Avian Pathology, 20: 597-606. DOI: https://www.doi.org/10.1080/03079459108418799

Erny K, Pallister J, and Sheppard M (1995). Immunological and molecular comparison of fowl adenovirus serotypes 4 and 10. Archives of Virology, 140: 491-501. DOI: https://www.doi.org/10.1007/BF01718426

Fadly AM, and Nazerian K (1982). Evidence for bursal involvement in the pathogenesis of hemorrhagic enteritis of turkeys. Avian Diseases, 26: 525533. DOI: https://www.doi.org/10.2307/1589898

Fadly AM, and Nazerian K (1984). Efficacy and safety of a cell-culture live virus vaccine for hemorrhagic enteritis of turkeys: laboratory studies. Avian Diseases, 183-196. DOI: https://www.doi.org/10.2307/1590141

Fadly AM, and Winterfield RW (1973). Isolation and some characteristics of an agent associated with inclusion body hepatitis and aplastic anaemia in chicken. Avian Diseases, 17: 182-193. DOI: https://www.doi.org/10.2307/1588936

Fadly AM, Winterfield RW, and Olander HJ (1976). Role of the bursa of Fabricius in the pathogenicity of inclusion body hepatitis and infectious bursal disease $\begin{array}{lll}\text { viruses. } & \text { Avian Diseases, } 20(3) \text { 467-477. DOI }\end{array}$ http://www.doi.org/10.2307/1589379

Fadly AM, Nazerian K, Nagaraja K, and Below G (1985). Field vaccination against hemorrhagic enteritis of turkeys by a cell culture live-virus vaccine. Avian Diseases, 29: 768-777. DOI: https://www.doi.org/10.2307/1590669.

Fender P, Boussaid A, Mezin P, and Chroboczek J (2005). Synthesis, cellular localization, and quantification of pentondodecahedron in serotype 3 adenovirus-infected cells. Virology, 340: 167-173. DOI:

https://www.doi.org/10.1016/j.virol.2005.06.030

Fingerut E, Gutter B, Gallili G, Michael A, and Pitcovski J (2003). A subunit vaccine against the adenovirus egg-drop syndrome using part of its fiber protein. Vaccine, 21: 2761-2766. DOI: https://www.doi.org/10.1016/s0264$\underline{410 x(03) 00117-8}$

Firth GA, Hall MJ, and McFerran JB (1981). Isolation of haemagglutinating adenolike virus related to virus 127 from an Australian poultry flock with an egg drop syndrome. Australian Veterinary Journal, 57: 239-242. DOI: https://www.doi.org/10.1111/j.1751-0813.1981.tb02669.x

Fitzgerald SD, and Reed WM (1989). A review of marble spleen disease of ringnecked pheasants. Journal of Wildlife Diseases, 25: 455-461. DOI: https://www.doi.org/10.7589/0090-3558-25.4.455

Fitzgerald SD, and Reed WM (1991). Pathogenesis of marble spleen disease in bursectomized and non-bursectomized ring-necked pheasants following oral inoculation with cell-culture-propagated virus. Avian Diseases, 35: 579-584. DOI: https://www.doi.org/10.2307/1591223.

Frolich K, Prusas C, Schettler E, and Hafez MH (2002). Antibodies to Adenoviruses in Free-Living Common Buzzards from Germany. Journal of Wildlife Diseases, 38(3): 633-636. DOI: https://www.doi.org/10.7589/0090$\underline{3558-38.3 .633}$

Fujiwara H, Tanaami S, Yamaguchi M, and Yoshino T (1975). Histopathology of hemorrhagic enteritis in turkeys. National Institute of Animal Health quarterly (Tokyo), 15(2): 68-75. PMID: 170543 .

Gale C, and Wyne JW (1957). Preliminary observations on hemorrhagic enteritis of $\begin{array}{lllll}\text { turkeys. } & \text { Poultry } & \text { Science, } 36: & \end{array}$ https://www.doi.org/10.3382/ps.0361267

Ganesh K, and R Raghavan (2000). Hydropericardium hepatitis syndrome of broiler poultry: current status of research. Research in Veterinary Science, 68: 201206. DOI: https://www.doi.org/10.1053/rvsc.1999.0365 
Ganesh K, Raghavan R, Gowda RNS, Satyanaryana ML, and Suryanaryana VVS (2002). Purification and characterization of the aetiological agent of hydropericardium hepatitis syndrome from infected liver tissue of broiler chickens. Tropical Animal Health and Production, 34: 7-17. DOI: https://www.doi.org/10.1023/A:1013777509538

Giovanardi D, Lupini C, Pesente P, Rossi G, Ortali G, and Catelli E (2014). Longitudinal field studies of Avian Metapneumovirus and turkey hemorrhagic enteritis virus in turkeys suffering from colibacillosis associated mortality. Veterinary Research Communication, 38: 129-137. DOI: https://doi.org/10.1007/s11259-014-9596-Z

Goodwin MA (1993). Adenovirus inclusion body ventriculitis in chickens and captive bobwhite quail (Colinus virginianus). Avian Diseases, 37: 568-571. DOI: https://www.doi.org/10.1007/s11259-014-9596-Z

Gomez-Villamandos JC, Carranza J, Sierra MA, Carrasco L, Hervas J, Blanco A, and Fernandez A (1994). Hemorrhagic enteritis by adenovirus-like particles in turkeys: a possible pathogenic mechanism. Avian Diseases, 38: 647-652. DOI: https://www.doi.org/10.2307/1592093

Gomis S, Goodhope R, Ojkic D, and Willson P (2006). Inclusion body hepatitis as a primary disease in broilers in Saskatchewan, Canada. Avian Diseases, 50(4): 550-555. DOI: https://www.doi.org/10.1637/7577-040106r.1

Grafl B, Prokofieva I, Wernsdorf P, Dublecz K, and Hess M (2015). Clinical signs and progression of lesions in the gizzard are not influenced by inclusion of ground oats or whole wheat in the diet following experimental infection with pathogenic fowl adenovirus serotype 1. Avian Pathology, 44: 230-236. DOI: https://www.doi.org/10.1080/03079457.2015.1028886

Grgić H, Philippe C, Ojkić D, and Nagy E (2006). Study of vertical transmission of fowl adenoviruses. Canadian Journal of Veterinary Research, 70: 230-233. Available at: https://www.ncbi.nlm.nih.gov/pubmed/16850947

Grgic H, Yang DH, and Nagy E (2011). Pathogenicity and complete genome sequence of a fowl adenovirus serotype 8 isolate. Virus Research, 156(1-2): 91-97. DOI: https://www.doi.org/10.1016/j.virusres.2011.01.002

Grimes TM, and King DJ (1977). Effect of maternal antibody on experimental infections of chickens with a type-8 avian adenovirus. Avian Diseases, 21: 97-112. DOI: https://www.doi:10.2307/1589368

Gross WB, and Moore WEC (1967). Hemorrhagic enteritis of turkeys. Avian Diseases, 11: 296-307. PMID: 5298527.

Günes A, Marek A, Grafl B, Berger E, and Hess M (2012). Real-time PCR assay for universal detection and quantitation of all five species of fowl adenoviruses (FAdV-A to FAdV-E). Journal of Virological Methods, 183(2): 147-153. DOI: https://www.doi.org/10.1016/j.jviromet.2012.04.005

Gulka CM, Piela TH, Yates VJ, and Bagshaw C (1984). Evidence of exposure of waterfowl and other aquatic birds to the hemagglutinating duck adenovirus identical to EDS 76 virus. Journal of Wildlife Diseases, 20: 1-5. DOI:

https://www.doi.org/10.7589/0090-3558-20.1.1

Hafez HM (2011). Avian adenoviruses infection with special attention to Inclusion body hepatitis/hydropericardium syndrome and egg drop syndrome. Pakistan Veterinary Journal, 31(2): 85-92. Available at:

https://agris.fao.org/agris-search/search.do?recordID=PK2011000971

Helmboldt CF, and Frazier MN (1963). Avian hepatic inclusion bodies of unknown significance. Avian Diseases, 7: 446-450. DOI: https://www.doi.org/10.2307/1587881

Henning P, Lundgren E, Carlsson M, Frykholm K, Johannisson J, Magnusson MK, Tång E, Franqueville L, Hong SS, Lindholm L et al. (2006). Adenovirus type 5 fiber knob domain has a critical role in fiber protein synthesis and encapsidation. Journal of General Virology, 87: 3151-3160. DOI: https://www.doi.org/10.1099/vir.0.81992-0

Hess M (2000). Detection and differentiation of avian adenoviruses: A review. Avian Pathology, 29(3): 195-206. DOI: https://www.doi.org/10.1080/03079450050045440

Hess M (2012). Vertical transmission and clinical signs in broiler breeders and broilers experiencing adenoviral gizzard erosion. Avian Pathology, 41: 599604. DOI: https://www.doi.org/10.1080/03079457.2012.740614

Hess M (2013). Avidenovirus infections. In: Swayne DE, Swayne JR, McDougald LR, Nolan LK, Suarez DL, and Nair V. editors. Diseases of Poultry, 13th ed. Iowa: Blackwell Publishing Professional Ames, pp. 290-300. Available at: https://www.wiley.com/en-ag/Diseases+of+Poultry,+13th+Edition-p9781118719732

Hess M, Alain C, Rob WHR, Jadwiga C, and Bernard J (1995). The avian adenovirus Penton: Two fibers and onebase. Journal of Molecular Biology, 252: 379-385. DOI: https://www.doi.org/10.1006/jmbi.1995.0504

Hess M, Blocker H, and Brandt P (1997). The complete nucleotide sequence of the egg drop syndrome virus, an intermediate between mastadenoviruses and aviadenoviruses. $\quad$ Virology, 238: 145-156. DOI: https://www.doi.org/10.1006/viro.1997.8815
Higashihara M, Hiruma M, Houdatsu T, Takai S, and Matumoto M (1987). Experimental infection of laying chickens with egg-drop syndrome 1976 virus. Avian Diseases, 31: 193-196. DOI https://www.doi.org/10.2307/1590794

Hoerr FJ (2010). Clinical aspects of immunosuppression in poultry. Avian Diseases, 54: 2-15. DOI: https://www.doi.org/10.1637/8909-043009-review.1

Hong SS, Habib NA, Franqueville L, Jensen S, and Boulanger PA (2003). Identification of adenovirus (Ad) penton base neutralizing epitopes by use of sera from patients who had received conditionally replicative Ad (Addl1520) for treatment of liver tumors. Journal of Virology, 77: 10366-10375. DOI:

https://www.dx.doi.org/10.1128\%2FJVI.77.19.10366-10375.2003

Hong SS, Szolajska E, Schoehn G, Franqueville L, Myhre S, Lindholm L, Ruigrok RW, Boulanger P, and Chroboczek J (2005). The $100 \mathrm{~K}$ chaperone protein from adenovirus serotype 2 (Subgroup $C$ ) assists in trimerization and nuclear localization of hexons from subrroups $\mathrm{C}$ and B adenoviruses. Journal of $\begin{array}{llll}\text { Molecular } & \text { Biology, } & 352: & 125-138 .\end{array}$ https://www.doi.org/10.1016/j.jmb.2005.06.070

Hosseini H, and Morshed R (2012). Molecular identification of fowl adenovirus associated with inclusion body hepatitis in Iran. Iranian Journal of Virology, 6: 7-12. Available at: http://journal.isv.org.ir/article-1-102-en.html

Howell J (1982). Egg drop syndrome in Ross Brown hens: An interim report. Surveillance, 9: 10-11. Available at: http://www.sciquest.org.nz/node/47875

Hussain I, Choi CU, Rings BS, Shaw DP, and Nagaraja KV (1993). Pathogenesis of hemorrhagic enteritis virus infection in turkeys. Journal of Veterinary Medicine Series B, 40: 715-726. DOI: https://www.doi.org/10.1111/j.14390450.1993.tb00196.x

Ianconescu M, McCapes RH, Bankowski RA, Kelly BJ, and Ghazikhanian GY (1985). Hemorrhagic enteritis of turkeys in California: Serologic study of hemorrhagic enteritis virus antibody with an enzyme-linked immunosorbent $\begin{array}{llll}\text { assay. Avian } & \text { 29: }\end{array}$ https://www.doi.org/10.2307/1590496

Itakura C, and Carlson HC (1975). Electron microscopic findings of cells with inclusion bodies in experimental hemorrhagic enteritis of turkeys. Canadian Journal of Comparative Medicine, 39: 299-304. Available at: http://www.ncbi.nlm.nih.gov/pmc/articles/pmc1277461/

Itakura C, Yasuba M, and Goto M (1974). Histopathological studies on inclusion body hepatitis in broiler chickens. Japanese Journal of Veterinary Science, 36(4): 329-340. DOI: https://www.doi.org/10.1292/jvms1939.36.329

Ivanics É, Palya V, Glávits R, Dán Á, Pálfi V, Révész T, and Benkő M (2001). The role of egg drop syndrome virus in acute respiratory disease of goslings. Avian Pathology, 30: 201-208. DOI https://www.doi.org/10.1080/03079450120054604

Jack SW, and Reed WM (1990). Pathology of experimentally induced quail bronchitis. Avian Diseases, 34: 44-51. DOI: https://www.doi.org/10.2307/1591332.

Jack SW, Reed WM, and Burnstein T (1994). The pathogenesis of quail bronchitis. Avian Diseases, 38: 548-556. DOI: https://www.doi.org/10.2307/1592078

Joubert HW, Aitchison H, Maartens LH, and Venter EH (2014). Molecular differentiation and pathogenicity of Aviadenoviruses isolated during an outbreak of inclusion body hepatitis in South Africa. The Journal of the South African Veterinary Association, 85: 1-8. Available at: http://www.dx.doi.org/10.4102/jsava.v85i1.1058.

Jucker MT, McQuiston JR, van den Hurk JV, Boyle SM, and Pierson FW (1996). Characterization of the haemorrhagic enteritis virus genome and the sequence of the putative penton base and core protein genes. Journal of General Virology, 77(3): 469-479. DOI: https://www.doi.org/10.1099/0022-1317-77$\underline{3-469}$

Kajan GL, Sameti S, and Benko M (2011). Partial sequence of the DNA-dependent DNA polymerase gene of fowl adenoviruses: a reference panel for a general diagnostic PCR in poultry. Acta Veterineria Hungarica, 59(2): 279-285. DOI: https://www.doi.org/10.1556/avet.2011.006

Kajan GL, Kecskemeti S, Harrach B, and Benko M (2013). Molecular typing of fowl adenoviruses, isolated in Hungary recently, reveals high diversity. Veterinary Microbiology, 167: 357-363. DOI: https://www.doi.org/10.1016/j.vetmic.2013.09.025

Kawamura H, Shimizu F, and Tsubahara H (1964). Avian adenovirus: Its properties and serological classification. National Institute of Animal Health Quarterly (Tokyo), 4: 183-193. PMID: 14251567

Khawaja DA, Ahmad S, Rauf MA, Zulfiqar MZ, Mahmood SMI, and Hassan M (1988). Isolation of an adenovirus from hydropericardium syndrome in broiler chicks. Pakistan Journal of Veterinary Research, 1: 2-17. Avialable at: https://ci.nii.ac.jp/naid/10028216430/ 
Khan AA, Sabri AN, Mansoor MK, and Hussain I (2005). Hydropericardium syndrome in Pakistan: A review. World's Poultry Science Journal, 61: 647653. DOI: https://www.doi.org/10.1079/WPS200576

Kim JN, Byun SH, Kim MJ, Kim J, Sung HW, and Mo IP (2008). Outbreaks of hydropericardium syndrome and molecular characterization of Korean fowl adenoviral isolates. Avian Diseases, 52: 526-530. DOI: https://www.doi.org/10.1637/8178-112207-Case

Kim MS, Lim TH, Lee DH, Youn HN, Yuk SS, Kim BY, Choi SW, Jung CH, Han JH, and Song CS (2014). An inactivated oil-emulsion fowl Adenovirus serotype 4 vaccine provides broad cross-protection against various serotypes of fowl adenovirus. Vaccine, 32: 3564-3568. DOI: https://www.doi.org/10.1016/j.vaccine.2014.03.015

Ko G (2005). Rapid detection of infectious adenoviruses by mRNA real-time RtPCR. Journal of Virological Methods,

127: 148-153. DOI: https://www.doi.org/10.1016/j.jviromet.2005.02.017

Koncicki A, Tykałowski B, Stenzel T, Smiałek M, and Pestka DE (2012). Effect of infection of turkeys with haemorrhagic enteritis adenovirus isolate on the selected parameters of cellular immunity and the course of colibacillosis. Polish Journal of Veterinary Sciences, 15: 215-220. DOI: https://www.doi.org/10.2478/v10181-011-0136-2

Kumar R, Chnadra R, Shukla SK, Agarwal DK, and Kumar M (1997). Hydropericardium syndrome in India: A preliminary study on the causative agent and the control of the disease by inactivated autogenous vaccine. Tropical Animal Health and Production, 29: 103-107. DOI: https://www.doi.org/10.1007/bf02633014

Kumar R, Kumar V, Asthana M, Shukla SK, and Chandra R (2010). Isolation and identification of a fowl adenovirus from wild black kites (Milvus migrans). Journal of Wildlife Diseases, 46: 272-276. DOI: https://www.doi.org/10.7589/0090-3558-46.1.272

Lee S, Kim J, Seo T, No J, Kim H, Kim W, Choi H, Kang S, and Song J (2016). Genetic and molecular epidemiological characterization of a novel adenovirus in Antarctic penguins collected between 2008 and 2013. PLoS One, 11(6): Article number 157032. https://www.doi.org/10.1371/journal.pone.0157032

Li PH, Zheng PP, Zhang TF, Wen GY, Shao HB, and Luo QP (2017). Fowl adenovirus serotype 4: Epidemiology, pathogenesis, diagnostic detection, and vaccine strategies. Poultry Science, 96: 2630-2640. DOI: https://www.doi.org/10.3382/ps/pex087

Lim TH, Kim BY, Kim MS, Jang JH, Lee DH, Kwon YK, Lee JB, Park SY, Choi IS, and Song CS (2012). Outbreak of gizzard erosion associated with fowl adenovirus infection in Korea. Poultry Science, 91: 1113-1117. DOI: https://www.doi.org/10.3382/ps.2011-02050

Liu Y, Wan W, Gao D, Li Y, Yang X, Liu H, Yao H, Chen L, Wang C, and Zhao J (2016). Genetic characterization of novel fowl aviadenovirus 4 isolates from outbreaks of hepatitis-hydropericardium syndrome in broiler chickens in China. Emerging Microbes and Infections, 5(11): 117. DOI: https://www.dx.doi.org/10.1038\%2Femi.2016.115

Lobanov VA, Shcherbakova LO, Borisov VV, Drygin VV, Gusev AA, Iurov GK, Akopian TA, and Naroditskii BS (2000). Adenovirus KR95, isolated from chickens during an outbreak of hydropericarditis, is the pathogen of this disease. Voprosy virusologii, 45: 36-40. DOI: PMID: 10867994.

Lu Y, Lin D, Tasi H, Lee Y, Chui S, Lee C, and Huang S (1985). Outbreaks of egg drop syndrome 1976 in Taiwan and isolation of the etiological agent. Journal of the Chinese Society of Veterinary Science, 11: 157-165. Available at: https://vettech.nvri.gov.tw/Appendix/report/291.PDF

Mahmood MD, Khushi M, Masood R, Atif H, and Irshad H (2011). In process quality control factors affecting efficacy of hydropericardium syndrome virus vaccine. Pakistan Journal of Zoology, 43(1): 73-77. Available at: https://www.zsp.com.pk/73-77\%20(12)\%20PJZ-134-09.pdf

Manarolla G, Pisoni G, Moroni P, Gallazzi D, Sironi G, and Rampin T (2009). Adenoviral gizzard erosions in Italian chicken flocks. Veterinary Record, 164: 754-756. DOI: https://www.doi.org/10.1136/vr.164.24.754

Mansoor MK, Hussain I, Arshad M, and Muhammad G (2011). Preparation and evaluation of chicken embryo adapted fowl adenovirus serotype 4 vaccine in broiler chickens. Tropical Animal Health and Production, 43: 331-338. DOI: https://www.doi.org/10.1007/s11250-010-9694-Z

Manzoor S, and Hussain I (2003). Reverse passive haemagglutination (RPHA) test for the detection and quantification of hydropericardium syndrome virus. Pakistan Journal of Life and Social Sciences, 1: 141-143. Available at: http://www.pjlss.edu.pk/pdf_files/2003_2/141-143.pdf

Marek A, Schulz E, Hess C, and Hess M (2010). Comparison of the fibers of Fowl adenovirus A serotype 1 isolates from chickens with gizzard erosions in Europe and apathogenic reference strains. The Journal of Veterinary Diagnostic Investigation, 22: 937-941. DOI: https://www.doi.org/10.1177/104063871002200613
Marek A, Kosiol C, Harrach B, Kaja G, Schlötterer C, and Hess M (2013). The first whole genome sequence of a fowl adenovirus B strain enables interspecies comparisons within the genu s Aviadenovirus. Veterinary Microbiology, 166: 250-256. DOI: https://www.doi.org/10.1016/j.vetmic.2013.05.017

Markowski-Grimsrud CJ, and Schat KA (2003). Infection with chicken anemia virus impairs the generation of pathogen-specific cytotoxic $\mathrm{T}$ lymphocytes. Immunology, 109: 283-294. https://www.dx.doi.org/10.1046\%2Fj.1365-2567.2003.01643.x

Maartens LH, Joubert HW, Aitchison H, and Venter EH (2014). Inclusion body hepatitis associated with an outbreak of fowl adenovirus type 2 and type $8 \mathrm{~b}$ in broiler flocks in South Africa. The Journal of the South African Veterinary Association, 85: 1-5. DOI: https://www.doi.org/10.4102/jsava.v85i1.1146

Malkinson M, and Weisman Y (1980). Serological survey for the prevalence of antibodies to egg drop syndrome 1976 virus in domesticated and wild birds in Israel. Avian Pathology, 7: 483-490. DOI https://www.doi.org/10.1080/03079458008418425

Mase M, and Nakamura K (2014). Phylogenetic analysis of fowl adenoviruses isolated from chickens with gizzard erosion in Japan. Journal of Veterinary Medical Science, 76: 1535-1538. DOI: https://www.dx.doi.org/10.1292\%2Fjvms.14-0312

Mase M, Nakamura K, and Minami F (2012). Fowl adenoviruses isolated from chickens with inclusion body hepatitis in Japan, 2009-2010. Journal of Veterinary Medical Science, 74: 1087-1089. DOI: https://www.doi.org/10.1292/jvms.11-0443

Mase M, Mitake H, Inoue T, and Imada T (2009). Identification of group I-III avian adenovirus by PCR coupled with direct sequencing of the hexon gene. The Journal of Veterinary Medical Science, 71: 1239-1242. DOI: https://www.doi.org/10.1292/jvms.71.1239

Mase M, Nakamura K, and Imada T (2010). Characterization of Fowl adenovirus serotype 4 isolated from chickens with hydropericardium syndrome based on analysis of the short fiber protein gene. The Journal of Veterinary Diagnostic Investigation, 22 : 218-223. https://www.doi.org/10.1177\%2F104063871002200207

Matos M, Grafl B, Liebhart D, and Hess M (2016). The outcome of experimentally induced inclusion body hepatitis (IBH) by fowl aviadenoviruses (FAdVs) is crucially influenced by the genetic background of the host. Veterinary Research, 47: Article number 69. DOI: https://www.doi.org/10.1186/s13567$\underline{016-0350-0}$

Matsushima Y, Shimizu H, Phan TG, and Ushijima H (2011). Genomic characterization of a novel human adenovirus type 31 recombinant in the hexon gene. Journal of General Virology, 92(12): 2770-2775. DOI: https://www.doi.org/10.1099/vir.0.034744-0

Mazaheri A, Prusas C, Vob M, and Hess M (1998). Some strains serotype 4 of Fowl adenovirus cause inclusion body hepatitis and hydropericardium syndrome in chickens. Avian Pathology, 27: 269-276. DOI https://www.doi.org/10.1080/03079459808419335

McCraken RM, and McFerran JB (1978). Experimental reproduction of the egg drop syndrome 1976 with a haemagglutinating adenovirus. Avian Pathology, 7: 483-490. DOI: https://www.doi.org/10.1080/03079457808418304

McFerran JB, and Adair BM (1977). Avian adenoviruses: A review. Avian $\begin{array}{llll}\text { Pathology, } & \text { 6: } & 189-217 . & \text { DOI: }\end{array}$ https://www.doi.org/10.1080/03079457708418228

McFerran JB, and Smyth JA (2000). Avian adenovirus. Revue Scientifique et Technique (Paris), 19(2): 589-601. PMID: 10935281.

McFerran JB, Adair B, and Connor TJ (1975). Adenoviral antigens (CELO, QBV, GAL) chicken embryo lethal orphan, quail bronchitis virus, gallus adeno-like. American Journal of Veterinary Research, 36: 527-529. Available at: https://agris.fao.org/agris-search/search.do?recordID=US19750038452

McFerran JB, McCracken RM, Connor TJ, and Evans RT (1976). Isolation of viruses from clinical outbreaks of inclusion body hepatitis. Avian Pathology, 5(4): 315-324. DOI: https://www.doi.org/10.1080/03079457608418201

McFerran JB, Rowley HM, McNulty MS, and Montgomery LJ (1977). Serological studies on flock showing depressed egg production. Avian Pathology, 6: 405 413. DOI: https://www.doi.org/10.1080/03079457708418249

McFerran J, McCracken R, McKillop ER, McNulty MS, and Collins D (1978). Studies on a depressed egg production syndrome in Northern Ireland. Avian Pathology, 7: 35-47. DOI: https://www.doi.org/10.1080/03079457808418258

Meulemans G, Boschmans M, Berg TP, and Decaesstecker M (2001). Polymerase chain reaction combined with restriction enzyme analysis for detection and differentiation of fowl adenoviruses. Avian Pathology, 30(6): 655-660. DOI: https://www.doi.org/10.1080/03079450120092143

Meulemans G, Couvreur B, Decaesstecker M, Boschmans M, and van den Berg TP (2004). Phylogenetic analysis of fowl adenoviruses. Avian Pathology, 33(2): 164-170. DOI: https://www.doi.org/10.1080/03079450310001652086 
Mirzazadeh A, Asasi K, Schachner A, Mosleh N, Liebhart D, Hess M, and Grafl B (2019). Gizzard rrosion associated with fowl adenovirus infection in slaughtered broiler chickens in Iran. Avian Diseases, 63(4): 568-576. DOI: https://www.doi.org/10.1637/aviandiseases-d-19-00069

Mittal D, Jindal N, Tiwari AK, and Khokhar RS (2014). Characterization of fowl adenoviruses associated with hydropericardium syndrome and inclusion body hepatitis in broiler chickens. Virusdisease, 25: 114-119. DOI: https://www.doi.org/10.1637/aviandiseases-d-19-00069

Mohamed MHA, El-Sabagh IM, Abdelaziz AM, AlAli AM, Alramadan M, Lebdah MA, Ibrahim AM, and Al-Ankari AS (2018). Molecular characterization of fowl aviadenoviruses species $\mathrm{D}$ and $\mathrm{E}$ associated with inclusion body hepatitis in chickens and falcons indicates possible cross-species transmission. Avian Pathology, 47(4): 384-390. DOI: https://www.doi.org/10.1080/03079457.2018.1457769

Morshed R, Hosseini H, Langeroudi AG, and Fard MHB, and Charkhkar S (2017). Fowl adenoviruses $\mathrm{D}$ and $\mathrm{E}$ cause inclusion body hepatitis outbreaks in broiler and broiler breeder pullet flocks. Avian Diseases, 61: 205-210. DOI: https://www.doi.org/10.1637/11551-120516-reg.1

Nagaraja KV, Kang SY, and Newman JA (1985). Immunosuppressive effects of virulent strain of hemorrhagic enteritis virus in turkeys vaccinated against Newcastle disease. Poultry Science, 64: 588-590. DOI: https://www.doi.org/10.3382/ps.0640588

Nakamura K, Tanaka H, Mase M, Imada T, and Yamada M (2002). Pancreatic necrosis and ventricular erosion in adenovirus associated hydropericardium syndrome in broilers. Veterinary Pathology, 39: 403-406. DOI: https://www.doi.org/10.1354\%2Fvp.39-3-403

Nakamura K, Mase M, Yamaguchi S, and Yuasa N (2000). Induction of hydropericardium in one day old specific pathogen free chicks by adenovirus from inclusion body hepatitis. Avian Diseases, 44: 192-196. DOI: https://www.doi.org/10.2307/1592524

Nakamura K, Mase M, Yamamoto Y, Takizawa K, Kabeya M, Wakuda T, Matsuda M, Chikuba T, Yamamoto Y, Ohyama T et al. (2011). Inclusion body hepatitis caused by fowl adenovirus in broiler chickens in Japan, 2009-2010. Avian Diseases, 55(4): 719-723. DOI: https://www.doi.org/10.1637/9813052511-case. 1

Nateghi E, Razmyar J, and Bassami MR (2014). Molecular characterization of avian adenoviruses in Iranian broiler flocks. Iran Journal of Veterinary Research, 15 : 164-167. https://www.dx.doi.org/10.22099/ijvr.2014.2365

Naeem K, and Akram HS (1995). Hydropericardium outbreaks in pigeon flock. Veterinary Record, 138: 296-297. DOI: https://www.doi.org/10.1136/vr.136.12.296

Naeem K, Rahim K, and Majeed IU (2001). Post infection dissemination pattern of avian adenovirus involved in hydropericardium syndrome. Pakistan Veterinary Journal, 21: 152-156. Avialable at: http://www.pvj.com.pk/pdffiles/21_3/152-156.pdf

Nawathe DR, and Abegunde A (1980). Egg drop syndrome 76 in Nigeria: Serological evidence in commercial farms. Veterinary Record, 107: 466-467. DOI: https://www.doi.org/10.1136/vr.107.20.466

Nicklin SA, Wu E, Nemerow GR, and Baker AH (2005). The influence of adenovirus fiber structure and function on vector development for gene $\begin{array}{llll}\text { therapy. Molecular Therapy, 12: 384-393. DOI: } & \end{array}$ https://www.doi.org/10.1016/i.ymthe.2005.05.008

Niczyporuk JS (2016). Phylogenetic and geographic analysis of fowl adenovirus field strains isolated from poultry in Poland. Archives of Virology, 161(1): 33-42. DOI: https://www.doi.org/10.1007/s00705-015-2635-4

Niczyporuk JS (2017). Molecular characterisation of fowl adenovirus type 7 isolated from poultry associated with inclusion body hepatitis in Poland. $\begin{array}{llll}\text { Archives of } \quad \text { Virology, 162: 1325-1333. DOI: } & \end{array}$ https://www.doi.org/10.1007/s00705-017-3240-5

Niczyporuk JS, Wozniakowski G, Salamonowicz ES, and Czekaj H (2013). Effect of fowl adenovirus on replication of vaccine strain of Marek's disease virus in chickens. Bulletin of the Veterinary Institute in Pulawy, 57: 467-472. DOI: https://www.doi.org/10.2478/bvip-2013-0081

Niczyporuk JS, Samorek-Salamonowicz E, and Czekaj H (2012). Occurrence of Adenovirus field strains in birds infected with Marek's disease virus. Bulletin of the Veterinary Institute in Pulawy, 56: 435-440. DOI: https://www.doi.org/10.2478/v10213-012-0077-2

Niu Y, Sun Q, Liu X, and Liu S (2019). Mechanism of fowl adenovirus serotype 4induced heart damage and formation of pericardial effusion. Poultry Science, 98: 1134-1145. DOI: https://www.doi.org/10.3382/ps/pey485

Niu Y, Sun Q, Zhang G, Sun W, Liu X, Xiao Y, and Liu S (2018). Epidemiological investigation of outbreaks of fowl adenovirus infections in commercial chickens in China. Transboundary and Emerging Diseases, 65: 121-126. DOI: https://www.doi.org/10.1111/tbed.12691
Ojkic D, Krell PJ, Tuboly T, and Nagy E (2008). Characterization of fowl adenoviruses isolated in Ontario and Quebec, Canada. Canadian Journal of Veterinary Research, 72(3): 236-241. Available at: https://www.ncbi.nlm.nih.gov/pubmed/18505186

Okuda Y, Ono M, Shibata I, and Sato S (2004). Pathogenicity of serotype 8 fowl adenovirus isolated from gizzard

erosions of slaughtered broiler chickens. The Journal of Veterinary Medical Science, 66: 1561-1566. DOI: https://www.doi.org/10.1292/jvms.66.1561

Okuda Y, Ono M, Shibata I, Sato S, and Akashi H (2006). Comparison of the polymerase chain reaction restriction fragment length polymorphism pattern of the fiber gene and pathogenicity of serotype- 1 fowl adenovirus isolates from gizzard erosions and from feces of clinically healthy chickens in Japan. Journal of Veterinary Diagnostic Investigation, 18: 162-167. DOI: https://www.doi.org/10.1177\%2F104063870601800204

Oliver-Ferrando S, Dolz R, Calderón C, Valle R, Rivas R, Pérez M, and Majó N (2017). Epidemiological and pathological investigation of fowl aviadenovirus serotypes $8 \mathrm{~b}$ and 11 isolated from chickens with inclusion body hepatitis in Spain (2011- 2013). Avian Pathology, 46: 157-165. DOI: https://www.doi.org/10.1080/03079457.2016.1232477

Olsen ND (1950). A respiratory disease (bronchitis) of quail caused by a virus. Veterinary Medicine, 46(1): Article number 22. Available at: https://pubmed.ncbi.nlm.nih.gov/14798774/

Ono M, Okuda Y, Yazawa S, Shibata I, Sato S, and Okada K (2003). Outbreaks of adenoviral gizzard erosion in slaughtered broiler chickens in Japan. Veterinary Record, 153: 775-779. DOI: https://www.doi.org/10.1136/vr.153.25.775

Ono M, Okuda Y, Shibata I, Sato S, and Okada K (2004). Pathogenicity by parenteral injection of fowl adenovirus isolated from gizzard erosion and resistance to reinfection in adenoviral gizzard erosion in chickens. Veterinary Pathology, 41: 483-489. DOI: https://www.doi.org/10.1354/vp.41-5-483

Palomino-Tapia V, Mitevski D, Inglis T, Van Der Meer F, and Abdul-Careem MF (2020). Molecular characterization of hemorrhagic enteritis virus (HEV) obtained from clinical samples in Western Canada 2017-2018. Viruses, 12: 941. DOI: https://www.doi.org/10.3390/v12090941

Pan Q, Liu L, Gao Y, Liu C, Qi X, Zhang Y, Wang Y, Li K, Gao L, Wang X et al. (2017b). Characterization of a hypervirulent fowl adenovirus 4 with the novel genotype newly prevalent in China and establishment of reproduction infection model of hydropericardium syndrome in chickens. Poultry Science, 96: 1581-1588. DOI: https://www.doi.org/10.3382/ps/pew431

Pan Q, Liu L, Wang Y, Zhang Y, Qi X, Liu C, Gao Y, Wang X, and Cui H (2017a). The first whole genome sequence and pathogenicity characterization of a fowl adenovirus 4 isolated from ducks associated with inclusion body hepatitis and hydropericardium syndrome. Avian Pathology, 46: 571-578. DOI: https://www.doi.org/10.1080/03079457.2017.1311006

Park HS, Lim IS, Kim SK, Kim TK, Park CK, and Yeo SG (2017). Molecular analysis of the hexon, penton base, and fiber- 2 genes of Korean fowl adenovirus serotype 4 isolates from hydropericardium syndrome-affected chickens. Virus Genes, 53: 111-116. DOI: https://www.doi.org/10.1007/s11262-016-1393-z

Parsons DG, Bracewell CD, and Parsons G (1980). Experimental infection of turkeys with egg drop syndrome 1976 virus and studies on the application of the haemagglutination inhibition test. Research in Veterinary Science, 29: 8992. DOI: https://www.doi.org/10.1016/S0034-5288(18)32691-2

Pehler-Harrington K, Khanna M, Waters CR, and Henrickson KJ (2004). Rapid detection and identification of human adenovirus species by adenoplex, a multiplex PCR-enzyme hybridization assay. Journal of Clinical Microbiology, 42: 4072-4076. DOI https://www.dx.doi.org/10.1128\%2FJCM.42.9.4072-4076.2004

Philippe C, Grgic H, Ojkic D, and Nagy E (2007). Serologic monitoring of a broiler breeder flock previously affected by inclusion body hepatitis and testing of the progeny for vertical transmission of fowl adenoviruses. Canadian Journal of Veterinary Research, 71: 98-102. Available at: http://www.ncbi.nlm.nih.gov/pmc/articles/pmc1829188/

Pilkington P, Brown T, Villegas P, McMurray B, Page RK, Rowland GN, and Thayer SG (1997). Adenovirus-induced inclusion body hepatitis in four-dayold broiler breeders. Avian Diseases, 41: 472-474. DOI: https://www.doi.org/10.2307/1592208

Pitcovski J, Fingerut E, Gallili G, Eliahu D, Finger A, and Gutter B (2005). A subunit vaccine against hemorrhagic enteritis adenovirus. Vaccine, 38: 4697 4702. DOI: https://www.doi.org/10.1016/j.vaccine.2005.03.049

Pomeroy BS, and Fenstermacher R (1937). Hemorrhagic enteritis in turkeys. Poultry Science, 16: 378-383. DOI: https://www.doi.org/10.3382/ps.0160378

Poss PE (1998). Turkey industry strategies for control of respiratory and enteric diseases. Poultry Science, 77: 1181-1185. DOI https://www.doi.org/10.1093/ps/77.8.1181 
Radwan MM, El-Deeb AH, Mousa MR, El-Sanousi AA, and Shalaby MA (2019). First report of fowl adenovirus $8 \mathrm{a}$ from commercial broiler chickens in Egypt: molecular characterization and pathogenicity. Poultry Science, 98(1): 97-104. DOI: https://www.doi.org/10.3382/ps/pey314

Rahimi M, and Minoosh SHZ (2015). Adenovirus like inclusion body hepatitis in a flock of broiler chickens in Kermanshah province, Iran. Veterinary Research Forum, 6(1): 95-98. Available at: https://www.ncbi.nlm.nih.gov/pubmed/25992259

Rahul S, Kataria JM, Senthilkumar N, Dhama K, Sylvester SA, and Uma R (2005). Association of fowl adenovirus serotype 12 with hydropericardium syndrome of poultry in India. Acta virologica, 49(2): 139-143. PMID: 16047743.

Ramis A, Marlasca MJ, Majo N, and Ferrer L (1992). Inclusion body hepatitis (IBH) in a group of eclectus parrots (Eclectus roratus). Avian Pathology, 21(1): 165-169. DOI: http://www.dx.doi.org/10.1080/03079459208418831

Raue R, and Hess M (1998). Hexon based PCRs combined with restriction enzyme analysis for rapid detection and differentiation of fowl adenoviruses and egg drop syndrome virus. Journal of Virological Methods, 73(2): 211-217. DOI: https://www.doi.org/10.1016/s0166-0934(98)00065-2

Raue R, Gerlach H, and Müller H (2005). Phylogenetic analysis of the hexon loop 1 region of an adenovirus from psittacine birds supports the existence of a new psittacine adenovirus (PsAdV). Archives of Virology, 150: 1933-1943. DOI: https://www.doi.org/10.1007/s00705-005-0578-X

Rautenschlein S (2000). Immunopathogenesis of haemorrhagic enteritis virus (HEV) in turkeys. Developmental and Comparative Immunology, 24: 237246. DOI: https://www.doi.org/10.1016/s0145-305x(99)00075-0

Rautenschlein S, and Sharma JM (1999). Response of turkeys to simultaneous vaccination with hemorrhagic enteritis and Newcastle disease viruses. Avian Diseases, 43: 286-292. DOI: https://www.doi.org/10.2307/1592619

Rautenschlein S, Suresh M, Neumann U, and Sharma J (1998). Comparative pathogenesis of haemorrhagic enteritis virus (HEV) infection in turkeys and chickens. Journal of Comparative Pathology, 119: 251-261. DOI: https://www.doi.org/10.1016/S0021-9975(98)80048-0

Reece RL, Barr DA, and Grix DC (1987). Pathogenicity studies with a strain of fowl adenovirus serotype 8 (VRI-33) in chickens. Australian Veterinary Journal, 64: 365-367. DOI: https://www.doi.org/10.1111/j.17510813.1987.tb09604.x

Roberts DM, Nanda A, Havenga MJ, Abbink P, Lynch DM, Ewald BA, Liu J, Thorner AR, Swanson PE, Gorgone DA et al. (2006). Hexon-chimaeric adenovirus serotype 5 vectors circumvent pre-existing anti-vector immunity. Nature, 441: 239-243. DOI: https://www.doi.org/10.1038/nature04721

Robinson CM, Singh G, Henquell C, Walsh MP, PeigueLafeuille H, Seto D, Jones MS, Dyer DW, and Chodosh J (2011). Computational analysis and identification of an emergent human adenovirus pathogen implicated in a respiratory fatality. Virology, 409: 141-147. DOI: https://www.doi.org/10.1016/j.virol.2010.10.020

Rosen MN, Hunter BF, and Brunetti OA (1965). Preliminary sudy of an infectious hepatitis in pheasants. Avian Diseases, 9(3): 382-393. DOI: https://www.doi.org/10.2307/1588368

Roy P, Kotteeswaran A, and Manickam R (2001). Serological, cytopathological and cytochemical studies on hydropericardium syndrome virus. Veterinarski Arhiv, 71(2): 97-103. Available at: https://hrcak.srce.hr/67856

Russell WC (2000). Update on adenovirus and its vectors. Journal of General Virology, 81: 2573-2604. DOI: https://www.doi.org/10.1099/0022-1317-81$\underline{11-2573}$

Russell WC (2009). Adenoviruses: update on structure and function. Journal of General Virology, $90(1)$ : $1-20 . \quad$ DOI: https://www.doi.org/10.1099/vir.0.003087-0

Rux JJ, Kuser PR, and Burnett RM (2003). Structural and phylogenetic analysis of adenovirus hexons by use of high-resolution X-ray crystallographic, molecular modeling, and sequence based methods. Journal of Virology, 77: 9553-9566. DOI: https://www.doi.org/10.1128/JVI.77.17.9553-9566.2003

Saban SD, Silvestry M, Nemerow GR, and Stewart PL (2006). Visualization of ahelices in a $6-\mathrm{A}^{\circ}$ ngstrom resolution cryoelectron microscopy structure of adenovirus allows refinement of capsid protein assignments. Journal of Virology, $\quad 80: \quad 12049-12059 . \quad$ DOI: https://www.dx.doi.org/10.1128\%2FJVI.01652-06

Saif YM (1998). Infectious bursal disease and hemorrhagic enteritis. Poultry Science, 77: 1186-1189. DOI: https://www.doi.org/10.1093/ps/77.8.1186

Saifuddin M, and Wilks CR (1990). Development of an enzyme linked immunosorbent assay to detect and quantify adenovirus in chicken tissue. Avian Disease, 34: 239-245. DOI: https://www.doi.org/10.2307/1591404

Schachner A, Marek A, Grafl B, and Hess M (2016). Detailed molecular analyses of the hexon loop-1 and fibers of fowl aviadenoviruses reveal new insights into the antigenic relationship and confirm that specific genotypes are involved in field outbreaks of inclusion body hepatitis. Veterinary $\begin{array}{lll}\text { Microbiology, } & 186: & 13-20 .\end{array}$ https://www.doi.org/10.1016/j.vetmic.2016.02.008

Schachner A, Matos M, Grafl B, and Hess M (2018). Fowl adenovirus-induced diseases and strategies for their control - review on the current global situation. Avian Pathology, 47(2): 111-126. DOI: https://www.doi.org/10.1080/03079457.2017.1385724

Schachner A, Marek A, Jaskulska B, Bilic I, and Hess M (2014). Recombinant FADV-4 fiber-2 protein protects chickens against hepatitis-hydropericardium syndrome (HHS). Vaccine, 32(9): 1086-1092. DOI https://www.doi.org/10.1016/j.vaccine.2013.12.056

Schelling SH, Garlick DS, and Alroy J (1989). Adenoviral hepatitis in a merlin (Falco columbarius). Veterinary Pathology, 26(6): 529-230. DOI: https://doi.org/10.1177\%2F030098588902600616

Schlör GM (1980). Frequency of antibody to adenovirus 127 in domestic ducks and wild waterfowl. Avian Diseases, 24: 91-98. DOI https://www.doi.org/10.2307/1589769

Schonewille E, Singh A, Gobel TW, Gerner W, Saalmuller A, and Hess M (2008). Fowl adenovirus (FAdV4) serotype 4 causes depletion of B and T cells in lymphoid organs in specific pathogen free chickens following experimental infection. Veterinary Immunology and Immunopathology, 121: 130-139. DOI: https://www.doi.org/10.1016/j.vetimm.2007.09.017

Schrenzel M, Oaks LJ, Rotstein D, Maalouf G, Snook E, Sandfort C, and Rideout B (2005). Characterization of a new species of adenovirus in falcons. Journal of Clinical Microbiology, 43: 3402-3413. DOI: https://www.doi.org/10.1128/JCM.43.7.3402-3413.2005

Shah MS, Ashraf A, Khan MI, Rahman M, and Qureshi JA (2012). A subunit vaccine against hydropericardium syndrome using adenovirus penton capsid $\begin{array}{llll}\text { protein. } & \text { Vaccine, } & 30(50): & 7153-7156 .\end{array}$ https://www.doi.org/10.1016/i.vaccine.2012.10.013

Shah MS, Ashraf A, Khan MI, Rahman M, Habib M, and Qureshi JA (2015) Molecular cloning, expression and characterization of $100 \mathrm{~K}$ gene of fowl adenovirus-4 for prevention and control of hydropericardium syndrome. $\begin{array}{llll}\text { Biologicals, } & 44: & 19-23 . & \text { DOI: }\end{array}$ https://www.doi.org/10.1016/j.biologicals.2015.10.002

Shah MS, Ashraf A, Khan MI, Rahman M, Habib M, Chughtai MI, and Qureshi JA (2017). Fowl adenovirus: history, emergence, biology and development of a vaccine against hydropericardium syndrome. Archive of Virology, 162: 1833-1843. DOI: https://www.doi.org/10.1007/s00705-017-3313-5

Sharma JM (1994). Response of specific-pathogen-free turkeys to vaccines derived from marble spleen disease virus and hemorrhagic enteritis virus. Avian Diseases, 38: 523-530. DOI: https://www.doi.org/10.2307/1592074

Singh A, Oberoi MS, Grewal GS, Hafez HM, and Hess M (2002). The use of PCR combined with restriction enzyme analysis to characterize fowl adenovirus field isolates from northern India. Veterinary Research Communications, 26: 577-585. DOI: https://www.doi.org/10.1023/A:1020299700907

Singh A, Grewal GS, Maiti NK, and Oberoi MS (2006). Effect of fowl adenovirus1 (IBH isolate) on humoral and cellular immune competency of broiler chicks. Comparative Immunology, Microbiology and Infectious Diseases, 29: 315-321. DOI: https://www.doi.org/10.1016/j.cimid.2006.08.001

Singh A, Bekele AZ, Patnayak DP, Jindal N, Porter RE, Mor SK, and Goyal SM (2016). Molecular characterization of quail bronchitis virus isolated from bobwhite quail in Minnesota. Poultry Science, 95: 2815-2818. DOI: https://www.doi.org/10.3382/ps/pew217

Smyth JA, Platten M, and McFerran J (1988). A study of the pathogenesis of egg drop syndrome in laying hens. Avian Pathology, 17: 653-666. DOI: https://www.doi.org/10.1080/03079458808436483

Steer PA, Kirkpatrick NC, O'Rourke D, and Noormohammadi AH (2009). Classification of fowl adenovirus serotypes by use of high resolution meltingcurve analysis of the hexon gene region. Journal of Clinical Microbiology, 47: 311-321. DOI: https://www.doi.org/10.1128/jcm.01567-08

Steer PA, O'Rourke D, Ghorashi SA, and Noormohammadi AH (2011). Application of high resolution melting curve analysis for typing of fowl adenoviruses in field cases of inclusion body hepatitis. Australian Veterinary Journal, 89(5): 184-192. DOI: https://www.doi.org/10.1111/j.17510813.2011.00695.x

Steer PA, Sandy JR, O'Rourke D, Scott PC, Browning GF, and Noormohammadi AH (2015). Chronological analysis of gross and histological lesions induced by field strains of fowl adenovirus serotypes $1,8 \mathrm{~b}$ and 11 in one-day-old chickens. Avian Pathology, 44: 106-113. DOI: https://www.doi.org/10.1080/03079457.2015.1007919

Suresh M, and Sharma J (1995). Hemorrhagic enteritis virus induced changes in the lymphocyte subpopulations in turkeys and the effect of experimental immunodeficiency on viral pathogenesis. Veterinary Immunology and 
Immunopathology, 45: 139-150. DOI: https://www.doi.org/10.1016/01652427(94)05323-K

Tan PK, Michou AI, Bergelson JM, and Cotton M (2001). Defining CAR as a cellular receptor for avian adenovirus CELO using a genomic analysis of the two viral fiber proteins. Journal of General Virology, 82: 1465-1472. DOI: https://www.doi.org/10.1099/0022-1317-82-6-1465

Taniguchi T, Yamaguchi S, Maeda M, Kawamura H, and Horiuchi T (1981). Pathological changes in laying hens inoculated with the JPA-1 strain of egg drop syndrome-1976 virus. National Institute of Animal Health quarterly (Tokyo), 21: 83-93. PMID: 6281663.

Tanimura N, Nakamura K, Imai K, Maeda M, Gobo T, Nitta S, Ishihara T, and Amano H (1993). Necrotizing pancreatitis and gizzard erosion associated with adenovirus infection in chickens. Avian Diseases, 37: 606-611. DOI: https://www.doi.org/10.2307/1591697

Thakor KB, Dave CJ, Prajapati KS, Fefar DT, and Jivani BM (2012). Molecular characterization of avian adenovirus causing inclusion body hepatitishydropericardium syndrome in broiler chicken of Anand, Gujarat, India. Veterinary World, 5(3): 178-182. http://www.dx.doi.org/10.5455/vetworld.2012.178-182

Tham VL, and Critchley KL (1981). Haemorrtiagic enteritis syndrome of turkeys. Australian Veterinary Journal, 57: 353-354. DOI: https://www.doi.org/10.1111/j.1751-0813.1981.tb05854.x

Toro H, Gonzales C, Cerda L, Reyes E, and Geisse C (2000). Chicken anemia virus and fowl adenoviruses: association to induce the inclusion body hepatitis/hydropericardium syndrome. Avian Diseases, 44: 51-58. PMID: 10737644.

Toro H, Gonzalez O, Escobar C, Cerda L, Morales MA, and Gonzalez C (2001). Vertical induction of the inclusion body hepatitis/hydropericardium syndrome with fowl adenovirus and chicken anemia virus. Avian Diseases, 45: 215-222. PMID: 11336070.

Tykałowski B, and Koncicki A (2017). Studies concerning the role of hemorrhagic enteritis virus in the pathology of turkeys conducted in the Department of Poultry Diseases in Olsztyn over the last 30 years. Medycyna Weterynaryjna, 73: 522-527. DOI: http://www.dx.doi.org/10.21521/mw.5777

Tykałowski B, Smiałek M, Koncicki A, Ognik K, Zdu 'nczyk Z, and Jankowski J (2019). The immune response of young turkeys to haemorrhagic enteritis virus infection at different levels and sources of methionine in the diet. BMC Veterinary Research, 15: Article number 387. DOI: https://www.doi.org/10.1186/s12917-019-2138-8

Van den Hurk JV (1990). Efficacy of avirulent hemorrhagic enteritis virus propagated in turkey leukocyte cultures for vaccination against hemorrhagic enteritis in turkeys. Avian Diseases, 34: 26-35. PMID: 2157395.

Van Eck J, Davelaar F, Heuvel-Plesman TAVD, Van Kol N, Kouwenhoven B, and Guldie F (1976). Dropped egg production, soft shelled and shell-less eggs associated with appearance of precipitins to adenovirus in flocks of laying fowls. Avian Pathology, 5: 261-272. DOI: https://www.doi.org/10.1080/03079457608418195

Viralzone (2015). dsDNA viruses, adenoviridae, aviadenovirus. Swiss institute of bioinformatics. Available at: http://www.viralzone.expasy.Org
Weier S (2013). Improved immunoprophylaxis against haemorrhagic enteritis virus $(\mathrm{HEV})$ in turkeys with repeated drinking water vaccination. Praktische Tierarzt, 94: 732-739. Available at: http://www.idt-biologika.de/

Wiethoff CM, Wodrich H, Gerace L, and Nemerow GR (2005). Adenovirus protein VI mediates membrane disruption following capsid disassembly. Journal of Virology, 79: 1992-2000. DOI: https://www.doi.org/10.1128/jvi.79.4.1992$\underline{2000.2005}$

Wilson FD, Wills RW, Senties-cue CG, Maslin WR, Stayer PA, and Magee DI (2010). High incidence of glomerulonephritis associated with inclusion body hepatitis in broiler chickens: routine histopathology and histomorphometric studies. Avian Diseases, 54: 975-980. DOI: https://www.doi.org/10.1637/9050-090709-reg.1

Xia J, Yao KC, Liu YY, You GJ, Li SY, Liu P, Zhao Q, Wen Rui Wu YP, Huang $\mathrm{XB}$, Cao SJ et al. (2017). Isolation and molecular characterization of prevalent fowl adenovirus strains in southwestern China during 2015-2016 for the development of a control strategy. Emerging Microbes and Infections, 6(11): e103. DOI: https://www.dx.doi.org/10.1038\%2Femi.2017.91

Xie Z, Fadl AA, Girshick T, and Khan MI (1999). Detection of avian adenovirus by polymerase chain reaction. Avian Diseases, 43: 98-105. DOI: https://www.doi.org/10.2307/1592767

Xie Z, Luo S, Fan Q, Xie L, Liu J, Xie Z, Pang Y, Deng X, and Wang X (2013). Detection of antibodies specific to the nonstructural proteins of fowl adenoviruses in infected chickens but not in vaccinated chickens. Avian Pathology, 42(5): 491-496. DOI https://www.doi.org/10.1080/03079457.2013.829553

Yamaguchi S, Imada T, Kawamura H, Taniguchi S, Saio H, and Shimamatsu K (1981). Outbreaks of egg-drop syndrome-1976 in Japan and its etiological agent. Avian Diseases, 25: 628-641. DOI: https://www.doi.org/10.2307/1589993

Yates VJ, and Fry DE (1957). Observations on a chicken embryo lethal orphan (CELO) virus. American Journal of Veterinary Research, 18: 657-660. PMID: 13444590.

Zadravec M, Slavec B, Krapez U, Kajan GL, Racnik J, Juntes P, Jursic CR, Benko M, and Zorman RO (2013). Inclusion body hepatitis (IBH) outbreak associated with fowl adenovirus type $8 \mathrm{~b}$ in broilers. Acta Veterineria (Beograd) 63: 101-110. DOI: https://www.doi.org/10.2298/AVB1301101Z

Zellen GK., Key DW, and Jack SW (1989). Adenoviral pancreatitis in guinea fowl (Numida meleagris). Avian Diseases, 33(3): 586-589. DOI https://doi.org/10.2307/1591126

Zhao J, Zhong Q, Zhao Y, Hu Y, and Zhang G (2015). Pathogenicity and complete genome characterization of fowl adenoviruses isolated from chickens associated with inclusion body hepatitis and hydropericardium syndrome in China. PLoS One, 10: e0133073. DOI: https://www.doi.org/10.1371/journal.pone.0133073

Zsak I, Szelely A, and Kisary J (1982). Experimental infection of young and laying geese with egg drop syndrome 1976 adenovirus strain B8/78. Avian Pathology, 11: 555-562. DOI: https://www.doi.org/10.1080/03079458208436130

Zubieta C, Schoehn G, Chroboczek J, and Cusack S (2005). The structure of the human adenovirus 2 penton. Molecular cell, 17: 121-135. DOI: https://www.doi.org/10.1016/j.molcel.2004.11.041 